This is the version of the paper as accepted by the journal, but before revision on proofs. Only the final version, as published in the journal, is the definitive one.

See : Alban Gautier, 'Butlers and Dish-Bearers in Anglo-Saxon Courts: Household Officers at the Royal Table', Historical Research, vol. 90, 2 (248), 2017, pp. 269-295.

\title{
Butlers and dish-bearers in Anglo-Saxon courts: household officers at the royal table
}

It has been recognized for a long time that meals, and particularly festive meals feasts or banquets, the words being, for all purposes, considered here as synonyms - played an important role in the life and political activity of Anglo-Saxon elites. ${ }^{1}$ Kings, thegns and other members of the elite-including some women-participated in feasts of political importance, in which both vertical and horizontal dimensions of power structures - that is, feelings of community and hierarchy - were at the same time established, consolidated and expressed. ${ }^{2}$ Instrumental in making such events a political success were a category of court officers which modern studies and translations of early medieval sources call 'butlers', 'cupbearers', 'dish-bearers' or 'seneschals'. Those officials were not mere waiters, but major figures of early (and also late) medieval courts: as Michel Rouche once wrote, 'the bouteiller would seem to us a humble sommelier if we did not know about the important political role assigned to the "wine receptions" of the day, compulsory drinking parties organized by all those who knew how to treat their guests and co-eaters'. ${ }^{3}$ Narrative sources show them serving kings and their fellow-drinkers at festive occasions, and documentary sources give such titles to a number of thegns who, for example, attest royal diplomas.

Drawing inspiration from the French expression 'officiers de bouche', generally used for the description of late medieval and early modern courts, ${ }^{4}$ I propose to call those people

${ }^{1}$ I presented earlier versions of this paper at seminars in Caen, Paris, Winchester and Cambridge: I am glad to thank all those who offered me useful advice, particularly Pierre Bauduin, Véronique Gazeau, Simon Keynes, Bruno Laurioux, Ryan Lavelle, Levi Roach and Barbara Yorke.

2 Probably the first book-length study of Anglo-Saxon feasting is E. Budde, Die Bedeutung der Trinksitten in der Kultur der Angelsachsen (Duisburg, 1906). Also see, among more recent studies, D. Bullough, Friends, Neighbours and Fellow-Drinkers: Aspects of Community and Conflict in the Early Medieval West (Cambridge, 1991); H. Magennis, Anglo-Saxon Appetites: Food and Drink and their Consumption in Old English and Related Literature (Dublin, 1999); S. Pollington, The MeadHall: The Feasting Tradition in Anglo-Saxon England (Hockwold-cum-Wilton, 2003); A. Gautier, Le festin dans l'Angleterre anglo-saxonne ( $V^{e}-X I^{e}$ siècle) (Rennes, 2006). See also M.J. Enright, Lady with a Mead Cup: Ritual, Prophecy and Lordship in the European Warband from La Tène to the Viking Age (Dublin, 1996); for a more archaeological point of view, see also C. Lee, Feasting the Dead: Food and Drink in Anglo-Saxon Burial Rituals (Woodbridge, 2007); B. Effros, Creating Community with Food and Drink in Merovingian Gaul (New York, 2002), explores this question for a geographical area which had much in common with early Anglo-Saxon England.

${ }^{3}$ M. Rouche, 'Haut Moyen Âge occidental', in Histoire de la vie privée, ed. P. Ariès and G. Duby (5 vols., Paris, 1985), i, 398-529, at 511.

${ }^{4}$ E.g. P. Moirez, Les offices de bouche à l'hôtel du roi de France, de Philippe VI à Charles VI (13281422) (unpublished thesis, Paris, 2002); Y. Morel, 'L'office de bouche à la cour de Bourgogne de la fin du XIV ${ }^{\mathrm{e}}$ siècle au début du XV siècle', in La Cour du Prince. Cour de France, cours d'Europe, $X I I^{e}-X V^{e}$ siècle, ed. M. Gaude-Ferragu, B. Laurioux and J. Paviot (Paris, 2011), 251-70. 
'officers of the mouth': an admittedly anachronistic phrase, which nevertheless allows us to underscore their role in the political management of the royal table. That said, whether the people who are depicted in narrative sources in the act of serving the king, and those who bear titles to that effect in the documentary sources, were the same people is not evident at all: it is indeed one of the questions this article will try to address. Let us say for the moment that, pending answers, we must adopt a broad view and treat as 'officers of the mouth' all individuals who are characterized as such in the sources: that is, all characters mentioned in a source with any title usually translated as 'butler', 'cupbearer', 'dish-bearer' or 'seneschal'. Further discrimination will follow.

\section{Sources and parallels}

The study of Anglo-Saxon officers of the mouth has never been undertaken at length. There are a few pages in Kemble's The Saxons in England, ${ }^{5}$ and many later studies of wider scope dedicate some space to the question, without considering it systematically. ${ }^{6}$ The most comprehensive treatment of the subject has been that of L. M. Larson, which is now more than a century old, ${ }^{7}$ as is the more limited study of Edward the Confessor's court by J. H. Round. ${ }^{8}$

The sources for the study of officers of the mouth are few, varied, and problematic. Anglo-Saxon cup- and dish-bearers do not appear very frequently in narrative sources, and when they do, it is generally in late works. There is for example an Anglo-Saxon butler in an episode (to which I will come back later) of William of Malmesbury's History of the English Kings. Heroic and religious poems also mention people who serve the king, sometimes with the same vocabulary: butlers (byrelas) are mentioned as part of a feast in Beowulf; ${ }^{9}$ in Andreas, butlers (byrlas) and serving ministers (ombehtpegnas) pour a sinister drink of blood in the context of a cannibalistic banquet. ${ }^{10}$

But the richest sources about them are undoubtedly charters, more precisely their lists of subscription: officers are regularly mentioned among the witnesses who attested both royal diplomas and more private documents. Several online tools can also be used for their study:

\footnotetext{
5 J. M. Kemble, The Saxons in England (1849, reissued Cambridge,2011), 109-12.

${ }^{6}$ Most importantly, H.R. Loyn, The Governance of Anglo-Saxon England (1984).

${ }^{7}$ L. M. Larson, The King's Household in England before the Norman Conquest (Madison, WI, 1904).

8 J. H. Round, 'The officers of Edward the Confessor', English Historical Review, xix/1 (1904), 90-2.

${ }_{9}^{9}$ Beowulf, 1. 1161, in Klaeber's Beowulf, ed. R. D. Fulk, R. E. Bjork and J. D. Niles (4th ed., Toronto, 2008), 41.

10 'Andreas', 1. 1533-4, in The Vercelli Book, ed. G. P. Krapp (London, 1932), 45.
} 
the 'Electronic Sawyer' website provides an access to a revised version of Peter Sawyer's catalogue of Anglo-Saxon charters, along with the text of charters and a guide to the bibliography of each document;"11 the 'Prosopography of Anglo-Saxon England' (PASE) allows us to browse the database by name or by 'office' and 'occupation';12 the 'Kemble' website gives access to Simon Keynes's Atlas of Attestations, through which we can survey in one glance the presence of officers in witness-lists; ${ }^{13}$ the Dictionary of Old English, developed at the University of Toronto, provides a guide to the relevant vernacular vocabulary for words beginning with letters A to $\mathrm{G} ;{ }^{14}$ fortunately the main words we need to consider are included, but for the rest of the alphabet the older Bosworth \& Toller AngloSaxon Dictionary is also available online. ${ }^{15}$ Thanks to those electronic tools, it is possible today to produce a (hopefully) exhaustive list of officers of the mouth, such as the one compiled in the appendix. Some twenty charters - either genuine or not-mention officers of the mouth, mainly dish-bearers and butlers. They are few and apart in the early Anglo-Saxon period, but they become more numerous in the century and a half before the Norman conquest: beginning in the 920 s, we have a constant supply of names and titles of officers, especially in the reigns of Eadwig (955-9), Edgar (957-75) and Æthelred II (978-1016). To the officers mentioned in witness-lists we may add a few names from other parts of charters, and from other documents: Domesday Book mentions a few, English and Norman. But only subscription lists, along with the online tools developed around them, allow us to try a prosopographical approach: the method has its dangers, but if we do not forget that 'individual careers must always be placed in their documentary and historical context', and

11 Peter H. Sawyer, Anglo-Saxon Charters: An Annotated List and Bibliography (1968), online version, http://www.esawyer.org.uk/about/index.html. When there is such an edition, I cite charters from the volumes of the collection 'Anglo-Saxon Charters' (London, 1973-...), using the abbreviation system recommended by S. Keynes, 'Church councils, royal assemblies, and Anglo-Saxon royal diplomas', in Kingship, Legislation and Power in Anglo-Saxon England, ed. G. R. Owen-Crocker and B. W. Schneider (Woodbridge, 2013), 17-182, at 180-2. If the charter has not been published in this collection, I cite (except when stated) from the e-Sawyer website [accessed 8-13 Jun 2015]. In all cases, I provide the Sawyer number under the form $\mathrm{S}+$ Sawyer number.

12 Prosopography of Anglo-Saxon England (PASE), http://www.pase.ac.uk/index.html [accessed 8-13 Jun 2015].

13 S. Keynes, An Atlas of Attestations in Anglo-Saxon Charters, c. 670-1066 (Cambridge, 2002), online version, http://www.kemble.asnc.cam.ac.uk/node/30 [accessed 8-13 Jun 2015].

14 A. Cameron, A. C. Amos, A. D. Healey et al., Dictionary of Old English: A to G (DOE) (Toronto, 2007), online version, http://tapor.library.utoronto.ca/doe/dict/index.html [accessed 23-24 Oct 2015]

15 J. Bosworth, An Anglo-Saxon Dictionary, ed. T. N. Toller (Oxford, 1921) online version, http://bosworth.ff.cuni.cz [accessed 23-24 Oct 2015]. 
that they are useless without 'a reconstitution of the ways groups, mainly based on kinship worked and acted', it may prove rewarding. ${ }^{16}$

This study will also benefit from comparison with the situation of similar officers in other royal and princely courts of the same period, both in the Isles and on the Continent. Some material from Wales contains lists of officers, but it is probably of later date: the Laws of Hywel Dda, which describe the organization of a royal court, may have been edicted in the tenth century, but they are known only from late medieval manuscripts, and were probably heavily reworked in between. ${ }^{17}$ Irish material is not very useful here. The eighth-century lawtract Crith Gablach states how many officers may feast with a king in various circumstances, but the arrangements of a king's house do not mention officials similar to the ones known in England. ${ }^{18}$ Similarly, a poem about the legendary court at Tara gives the titles of members of a king's entourage, but none of them really matches the Anglo-Saxon evidence. ${ }^{19}$ In the tenthor eleventh-century saga Togail Bruidne Da Derga, King Conaire's champion Mac Cécht refuses to pour drink for his thirsty sovereign: Conaire has butlers, he says, let them serve him; ${ }^{20}$ but it is very difficult to gauge how close this isolated statement may be to the realities of medieval Irish courts.

Continental parallels are more rewarding, ${ }^{21}$ especially thanks to the work of German historians writing on Carolingian, Ottonian and Salian courts. ${ }^{22}$ Studies of the organization of Frankish courts by Belgian, French and German historians often comment on Archbishop Hincmar of Rheims' De ordine palatii, a description of the Carolingian palace. ${ }^{23}$ The early

${ }^{16}$ F. Bougard, G. Bührer-Thierry and R. Le Jan, 'Les élites du haut Moyen Âge. Identités, stratégies, mobilité', Annales. Histoire, sciences sociales, lxviii/4 (2013), 1079-1112, at 1104.

${ }^{17}$ The Law of Hywel Dda. Law Texts from Medieval Wales, ed. D. Jenkins (Llandysul, 1986): see the introduction, i-xlviii.

18 Crith Gablach, $\S 115-8$ and 134-5, ed. E. McNeill, 'The Law of Status or Franchise', Proceedings of the Royal Irish Academy, Section C, xxxvi (1921-4), 265-316, at 300-1 and 305-6.

${ }_{19}$ D. Ó Cróinín, Early Medieval Ireland, 400-1200 (London, 1995), 72.

20 R. O'Connor, The Destruction of Da Derga's Hostel. Kingship and Narrative Artistry in a Mediaeval Irish Saga (Oxford, 2013), 212.

${ }^{21}$ I explore those parallels at greater length in A. Gautier, 'Festin et politique: servir la table royale dans le haut Moyen Âge', in L'Alimentazione nell'alto Medioevo. Pratiche, simboli, ideologie (Spoleto: Settimane di studio del CISAM lxiii, forthcoming).

22 P. Schubert, 'Die Reichshofämter und ihre Inhaber bis um die Wende des 12. Jahrhunderts', Mitteilungen des Instituts für Österreichische Geschichtsforschung, xxxiv/3 (1913), 427-501; K. Bosl, 'Vorstufen der deutschen Königsdienstmannschaft. Begriffsgeschichtlisch-prosopographische Studien zur frühmittelalterlichen Sozial- und Verfassungsgeschichte', in Frühformen der Gesellschaft im mittelalterlichen Europa. Ausgewählte Beiträge zu einer Strukturanalyse der mittelalterlichen West (Munich, 1964), 228-76.

${ }^{23}$ Hincmar, De ordine palatii, ed. T. Gross and R. Schieffer (Hanover: MGH Fontes iuris iii, 1980); G. Waitz, Deutsche Verfassungsgeschichte, iii: Die Verfassung des fränkischen Reichs (2nd ed., Berlin, 1883); L. Halphen, Charlemagne et l'Empire carolingien (Paris, 1947), 155-60; F.-L. Ganshof, 
Capetian court of the eleventh and early twelfth century has been the subject of much work, including a recent reassessment in Éric Bournazel's biography of Louis VI. ${ }^{24}$ Finally, there have been less detailed - but still useful - studies of some princely courts of Northern France, most importantly that of the dukes of Normandy. ${ }^{25}$ Continental parallels share to some extent the vocabulary of English documents, and may shed light on obscure mentions in them; they may also leave us with more questions. Among many, were Anglo-Saxon officers of the mouth mere dignitaries, provided with titles without performing any actual service or ceremonial function? That was indeed the case of the chancellor at the Capetian court: that title was bestowed on a bishop (often the archbishop of Rheims), while the office was in fact carried out by royal notaries and chaplains; moreover, it was often vacant, and remained so from the late twelfth century onwards. ${ }^{26}$

Ecclesiastical sources should not be neglected as parallels of what existed in royal and princely courts, because the food cultures of lay and clerical communities were probably more similar than is sometimes thought; ${ }^{27}$ at least they were well aware of each other. In monastic communities, monks seem to have taken turns. According to the Rule of St Benedict, 'weekly servants of the kitchen' (septimanarii coquinae) had to work in turns under the supervision of a stable cellarer (cellerarius), and their service included serving their brothers at the table; ${ }^{28}$ as for the guests' kitchen and table, they had to be ministered by two monks chosen for a year and as many helpers as necessary. ${ }^{29}$ There are similar arrangements in Columbanus'

'Charlemagne et les institutions de la monarchie franque', in Karl der Große. Lebenswerk und Nachleben, i: Persönlichkeit und Geschichte, ed. H. Beumann (Düsseldorf, 1965), 349-93; J. Fleckenstein, 'Die Struktur des Hofes Karls des Großen im Spiegel von Hinkmars De ordine palatii', Zeitschrift des Aachener Geschichtsvereins, 1xxxiii (1976), 5-22; P. Depreux, Prosopographie de l'entourage de Louis le Pieux (781-840) (Sigmaringen, 1997).

${ }^{24}$ A. Luchaire, Histoire des institutions monarchiques de la France sous les premiers Capétiens (9871180) (2 vols., Paris, 1883); F. Lot and R. Fawtier, Histoire des institutions françaises au Moyen Âge, ii: Institutions royales (Les droits du Roi exercés par le Roi) (Paris, 1958); J.-F. Lemarignier, Le gouvernement royal aux premiers temps capétiens (987-1108) (Paris, 1965); É. Bournazel, Le gouvernement capétien au XII siècle (1108-1180). Structures sociales et mutations institutionnelles (Paris, 1975); O. Guillot, A. Rigaudière and Y. Sassier, Pouvoirs et institutions dans la France médiévale, i: Des origines à l'époque féodale (3rd ed., Paris, 1999); É. Bournazel, Louis VI le Gros (Paris, 2007).

25 A. Luchaire, Manuel des institutions françaises: période des Capétiens directs (Paris, 1892); D. Bates, Normandy before 1066 (1982), 155-6.

${ }^{26}$ Luchaire, Histoire des institutions, i, 184-7.

27 A. Gautier, 'Quelques pratiques de distinction des clercs anglo-saxons: entre condamnations et accommodements avec le siècle', in Théorie et pratiques des élites au haut Moyen Âge: conception, perception et réalisation sociale, ed. F. Bougard, R. Le Jan and H.-W. Goetz (Turnhout, 2011), 291308.

${ }^{28}$ Regula Benedicti, XXXV, 12-13, in La règle de saint Benoît, ed. H. Rochais (Paris, 1997), 82.

${ }^{29}$ Regula Benedicti, LIII, 17-18, ed. Rochais, 114-5. 
Communal Rule, which mentions 'whoever of the brethren, to whom the care of cooking or serving has been entrusted'. ${ }^{30}$ In Adomnán's Vita Columbae, Columba prophesies about a man, called Colgú, who is about to become the 'head' (primarius) of a church: when he sees his cupbearer (pincerna) 'enjoying himself at dinner with friends and swinging the servingjug round in a circle by its neck', he will know that he is about to die. ${ }^{31}$ The problem with that episode is that its context is rather obscure, which makes it difficult to use as a parallel for Anglo-Saxon situations: as Richard Sharpe admits, we cannot be sure whether Colgú was an abbot (served by a cupbearer within his monastery) or the lay proprietor of a church (served by a cupbearer outside the monastery). ${ }^{32}$

\section{Mentions of butlers and dish-bearers}

All these sources and parallels allow us to explore the status and occupation of officers of the mouth in Anglo-Saxon courts, especially in the tenth and eleventh century. Who were those officers? Were they always noblemen or were some of them of lower birth? What was their rank at court and among the elite? And what did they do exactly, how did they relate to the royal table? Did they serve kings in person — and, if so, in which circumstances — or did they just attest charters with pompous titles? And finally, why did they serve? Was service a privileged way to access the person of the king and make a career? I may not answer all those questions, for the documents are few and often inadequate; still, it is worth asking and testing them on the sources. But before that, we must see how the sources describe them.

In Anglo-Saxon and continental sources, officers of the mouth appear under a specific vocabulary. Their titles fall in two categories, which may be subsumed under the headwords 'butlers' and 'dish-bearers'. ${ }^{33}$ A butler or cupbearer (French bouteiller, échanson; German Schenk, Mundschenk) is known in Latin as pincerna (both in England and on the Continent), buticularius and scancio (both being rather frequent in Frankish sources, but very rare in England). ${ }^{34}$ Dish-bearers or seneschals (French sénéchal; German Truchseß) have a more

30 Columbanus, Regula Coenobialis, 2, in Sancti Columbani Opera, ed. G. S. M. Walker (Dublin, 1957), 146-7.

${ }^{31}$ Adomnán, Vita Columbae, I, 17, in Life of St Columba, ed. R. Sharpe (London, 1995), 124.

32 Ibid., 278-9, n. 103.

${ }^{33}$ See the useful summaries provided by S. Kreiker, 'Mundschenk', in Lexicon des Mittelalters, vol. vi (Turnhout, 1997), 908; W. Rösener, 'Seneschall', in Lexicon des Mittelalters, vol. vii (Turnhout, 1995), 1751-2; S. Kreiker, 'Truchseß', in Lexicon des Mittelalters, vol. viii (Turnhout, 1997), 106970.

${ }^{34}$ Scancio appears to have been specifically Germanic, but pincerna was always more frequent in Latin documents from German courts: Schubert, 'Reichshofämter', 440, 450. Buticularius became the 
varied Latin vocabulary. Infertor and siniscalcus are known from Frankish but not AngloSaxon documents; discifer is known on both sides of the Channel; but dapifer is the most frequent word, both in England and on the Continent. ${ }^{35}$ Both discifer and dapifer literally mean 'dish-bearer', but in the first case 'dish' should be understood as the disc-shaped object (discus), whereas in the second it refers to the culinary preparation that was inside (dapes). The word 'seneschal', which became the standard one in French-speaking courts, was not used in Anglo-Saxon England and probably came to England with the Normans: ${ }^{36}$ for that reason I will not use it when describing early English courts, and I will prefer the somewhat awkward 'dish-bearer' as an alternative: it is a straight translation of Old English discberend, a word which glosses Latin discifer in the Cotton-Cleopatra glossaries. ${ }^{37}$ To sum up, in England we find officers in charge of drinks mainly called pincernae, and officers in charge of food mainly called disciferi or dapiferi. It may be that, before the tenth century, either the dapifer or (less probably) the pincerna was sometimes called cellerarius, meaning the officer in charge of the cellar: a cellerarius appears in a charter of king Alfred, ${ }^{38}$ and there are also two cel' in a charter of Æthelwulf, probably an abbreviation for cellerarius. ${ }^{39}$

The standard Old English equivalents of those words were byrele (or birele, byrle) and discpegn (or discpen): they are the words Ælfric uses in his grammar to gloss discifer and pincerna. ${ }^{40}$ Byrele was probably a rather common word: it is attested in glossaries, translations, homilies, poetry, laws and charters. ${ }^{41}$ To mention but one example outside

standard word at the Capetian court, even if pincerna and pincernarius subsisted: Bournazel, Le gouvernement, 95-102. On the other hand, the Norman court did not use buticularius, but pincerna: see Recueil des actes des ducs de Normandie de 911 à 1066, ed. M. Fauroux (Caen, 1961), passim, and Regesta Regum Anglo-Normannorum. The Acta of William I (1066-1087), ed. D. Bates (Oxford, 1998), 1009-41.

${ }^{35}$ Even if sénéchal became the most current word in vernacular French, Latin documents from the Capetian court favour dapifer: Lot and Fawtier, Histoire des institutions, 52. So did Latin documents from German courts, even if infertor was sometimes used in Ottonian and Salian Germany: Schubert, 'Reichshofämter', 450. There is even an instance of Greek-sounding disciforus at the court of Otto III: Schubert, 'Reichshofämter', 445.

36 Siniscalcus was most frequent in Norman charters under William the Conqueror; dapifer was used but only came second: see Recueil des actes des ducs de Normandie de 911 à 1066, ed. M. Fauroux (Caen, 1961), passim.

37 DOE, 'discberend'.

38 S 348. S. Keynes and M. Lapidge, Alfred the Great: Asser's Life of King Alfred and Other Contemporary Sources (1983), 330, translate cellerarius (or hordere, to use the Old English word) by 'storekeeper' and consider that 'in the tenth century the official in question was probably known as a discthegn'. See also S. Foot, AEthelstan. The First King of England (New Haven, CT, 2011), 67.

${ }^{39} \mathrm{~S} 293$.

40 Alfrics Grammatik und Glossar, vol. 1: Text und Varianten, ed. J. Zupitza (Berlin, 1880), 303 and 315.

${ }^{41} \mathrm{DOE}$, 'byrle', has 11 entries from texts belonging to all those genres. 
charters, in the Old English Heptateuch, Pharaoh's chief butler (praepositus pincernarum in the Latin of Jerome's Vulgate) ${ }^{42}$ is described as a pare byrla ealdor ${ }^{43}$ Discpegn was more common than discberend: it is attested in charters, in a glossary and in one of Ælfric's homilies, whereas discberend only appears in glossaries and might be a mere calque of discifer. ${ }^{44}$ As a significant proof of the popularity of discpegn, we may note that it was adopted by high medieval Welsh courts: if the cupbearer (trullyat) had a Welsh name, the steward or dish-bearer was know as dysteyn, a direct loan from Old English. ${ }^{45}$ The word stigweard (literally, 'guardian of the enclosure') also appears, generally as a subordinate officer, different from the dapifer; but the fact that 'steward' became a standard word for a seneschal in Middle English suggests that their function was similar, albeit at a lower level. ${ }^{46}$ We may nevertheless ponder the fact that no original charter uses those terms in witness-lists, and that we must always rely on later copies, some of them possibly forgeries.

Looking for officials in the full text of charters (or, come to that, in PASE) is not always straightforward, and I have striven not to omit any of them while compiling the table in the appendix. For example, two charters-S 782 (printed by Susan Kelly from a reliable twelfth-century copy) ${ }^{47}$ and S 792 (a rather unreliable diploma only known by late copies, the earliest of which may be from the thirteenth century, and whose witness-list was probably copied on the previous one $)^{48}$, with different manuscript versions ${ }^{49}$ - include the abbreviation disc'. Kemble wrongly developed disc' as discipulus, ${ }^{50}$ but it clearly meant discifer. Eanulf, one the disc' mentioned in both lists, was probably the discifer of S 768 (an impeccable charter known by two copies, one of them contemporary). ${ }^{51}$ It may indicate either that the abbreviation was the work of a late copyist, or that it was a genuine Anglo-Saxon practice: no certainty can be reached here.

42 Gn 40.9, in Biblia Sacra iuxta Vulgatam versionem, ed. R. Weber and R. Gryson (4th ed., Stuttgart, 1994), 59.

43 DOE, 'byrle', citing The Old English Version of the Heptateuch, Alfric's Treatise on the Old and New Testament, and his Preface to Genesis, ed. S. J. Crawford (Oxford, 1922).

${ }^{44}$ DOE, 'discberend' and 'discpegn'.

${ }^{45}$ Law of Hywel Dda, ed. Jenkins, 12-4 and 25 (the queen also had a dysteyn, see p. 28).

${ }^{46}$ Larson, King's Household, 172-4.

${ }^{47} \mathrm{~S} 782$ (Pet 15).

48 S 792; see the commentary of S 782 in Charters of Peterborough Abbey, ed. S. E. Kelly, AngloSaxon Charters, xiv (Oxford, 2009), 250.

49 C. R. Hart, The Early Charters of Eastern England (Leicester, 1966), 172-5: the abbreviations appear at least in Hart's versions A (a thirteenth-century ms of Peterborough, which he prints) and D (a fourteenth-century Cotton manuscript, printed by both Kemble and Birch).

50 J. M. Kemble, Codex diplomaticus aevi Saxonici (London, 1845), vol. 3, 72 (dxlviii).

${ }^{51} \mathrm{~S} 768$ (Burt 23): he is 'Eanwulf 22' in PASE. See Charters of Burton Abbey, ed. P. Sawyer, AngloSaxon Charters, ii (Oxford, 1979), 38-9. 
The king and queen were not the only ones to enjoy the services of a butler or a dishbearer: so did æthelings. A charter written before 1014 mentions a certain Leofwine, discpegn of Edmund the ætheling:52 Edmund did become king himself for a few months in 1016, but he was probably only second or even third in line when the charter was drawn up. At exactly the same time, Edmund's brother Æthelstan was writing his own will, bequeathing eight hides and a horse to his discpen Ælfmær. ${ }^{53}$ Just as the title of ætheling was given to all sons (and sometimes grandsons) of a king, ${ }^{54}$ all of them — not only the designated heir-could have their own household. An original document from the early 990s includes, among people attending a shire-court in Berkshire, one Æfic, 'dish-bearer of the æthelings' (in the plural). ${ }^{55}$ It looks as if the court of Æthelred II, who then had many children still in their infancy, ${ }^{56}$ included as a sub-entity a kind of 'household of the royal children'; those children, once come of age, would have gathered their own retinue, including a dish-bearer (and probably a butler). The fact that there were no royal children with clear status during almost the whole eleventh century, in a kingdom which cruelly lacked heirs to the throne, unfortunately prevents us from testing this hypothesis. ${ }^{57}$

Below the æthelings' level, we come to a social rank where people appear less and less in the sources: we cannot really observe the household officers of great lords, secular and ecclesiastical. There are a few episcopal officials in William of Malmesbury's Vita Wulfstani, a life of Wufstan II of Worcester (an Anglo-Saxon bishop whose career straddles the Norman conquest) adapted from an Old English original written by the monk Coleman around 1100.58 Two episodes from that source (both situated after the Norman conquest) show pincernae (in the plural) ministering to the many knights of the bishop's household, and a dapifer outraged with his master's decision to have paupers and noblemen sit down together at a banquet in his

${ }^{52} \mathrm{~S} 1422$ (Sherb 14): 'Lofwine cepelinges discpen'; the name is spelt Leofwine in another ms.

${ }^{53} \mathrm{~S} 1503$ (CantCC 142): 'AElmere minon discpene'.

54 D. N. Dumville, 'The cetheling: a study in Anglo-Saxon constitutional history', Anglo-Saxon England, viii (1979), 1-33.

55 S 1454 (CantCC 53): 'AEfic para cepelinga discten'.

56 We know at least six sons and three daughters from his first wife, who were born from the mid980s: R. Lavelle, Aethelred II, King of the English, 978-1016 (Stroud, 2002), 82.

${ }^{57}$ Edmund Ironside's reign was too short and troublesome to allow anything to be settled; Harthacnut, the son of Cnut, was sent to Denmark, and his brothers Swegn and Harold Harefoot were more or less illegitimate; Harold I, Edward the Confessor and William Rufus were childless; the sons of Swegn Forkbeard, Harold II and William I were already adults when their father came to the throne, and anyway the reigns of the first two were too short to allow any observation.

58 William of Malmesbury, Vita Wulfstani, in Saints' Lives: Lives of SS. Wulfstan, Dunstan, Patrick, Benign and Indract, ed. M. Winterbottom and R. M. Thomson (Oxford, 2002): see the introduction. 
hall. ${ }^{59}$ But it is difficult to say if those episodes belonged to Coleman's first redaction, and we cannot know whether they reflect late Anglo-Saxon or twelfth-century usage.

Only in Domesday Book do we find possible mentions of officials from the household of lay grandees. Normans of high rank appear to have brought their own 'officiers de bouche': Hugh, earl of Chester, was linked to one Richard pincerna, ${ }^{60}$ and Roger, earl of Shrewsbury, to one Robert pincerna. ${ }^{61}$ Both are actually known from charters: they served those two lords and held land from them. ${ }^{62}$ But Domesday soubriquets are highly difficult to manage: when a man is called pincerna, we have no way of knowing whether he was called that because he was indeed a household officer, because an ancestor of his had been one, or because he or his father had performed in one memorable occasion, for ever lost to us. This was indeed the case with a whole Anglo-Norman dynasty from Montacute, Somerset: the descendants of one 'Alfred the Butler' (Aluredus pincerna) were called William pincerna, Robert pincerna and Richard pincerna, and it is very improbable that all of them were actual butlers. ${ }^{63}$ Even in witness-lists the case is not always proven: once we leave the domain of royal officials, it may be difficult to decide whether an apposition reflects a real occupation or was just a nickname. 'Leofric the dish-bearer', mentioned in the $1043 \times 1045$ will of Thurstan, a thegn of East Anglia, was probably a servant of the Mercian house of Leofric: his name suggests a connection with the ducal family of Mercia, and 'Ælfgar the earl's son' attests the will at the head of one of the lists, precisely that in which Leofric the dish-bearer appears. ${ }^{64}$ Conversely, discpeng here could be a soubriquet, with no particular indication about Leofric's occupation or title.

\section{Rank at court}

It is safer then to concentrate on royal dish-bearers and butlers. The recurrence of the same names in successive charters suggests that, at least from the tenth century, they had a

59 William of Malmesbury, Vita Wulfstani, iii, 16 and 20, ed. Winterbottom and Thomson, 130-3 and 138-9.

60 Domesday Book, Ches., fol. 265r. I quote from the Phillimore edition, by county (i.e., volume) and folio: Domesday Book (29 vols., Chichester, 1975-1992).

${ }^{61}$ Domesday Book, Salop., fol. 253v, 255r, 256r.

62 K. S. B. Keats-Rohan, Domesday People. A Prosopography of Persons Occurring in English Documents, 1066-1166, vol. i: Domesday Book (Woodbridge, 1999), 367 and 392.

${ }^{63}$ Keats-Rohan, Domesday People, 143-4.

${ }^{64}$ S 1531, in Anglo-Saxon Wills, ed. D. Whitelock (Cambridge, 1930), no. 81, 'Leuerich discpeng'. S. Baxter, The Earls of Mercia. Lordship and Power in Late Anglo-Saxon England (Oxford, 2007), 243 , considers this charter as a proof that pre-conquest non-royal household employed seneschals; but apart from the households of æthelings, this is the only relevant charter he can quote. 
stable position at court: ministri did not take turns to serve in the royal hall, as monks did in their refectories. A king's (or a queen's) officers of the mouth were senior staff, ranking high in the courtly hierarchy: they were not menial servants like cooks (coqui) or breadmasters (pistores). The latter are known from Carolingian documents, ${ }^{65}$ but I have not found any Anglo-Saxon example that may be connected with an office at a royal court. There are a few cooks, but they do not seem to have been as important as butlers and dish-bearers. It is true that, in early twelfth-century France, some royal cooks were important people, even with an occasional military role, ${ }^{66}$ but they never ranked as high as the four great court officialssénéchal, bouteiller, chambrier and connétable. Rather, queux (cooks) were on the level of other servants placed under the authority of the main officials, such as échansons under the bouteiller or maréchaux under the connétable. ${ }^{67}$ We have admittedly two examples of an English cook mentioned alongside a butler. The first one is a diploma of Wiglaf, king of the Mercians (827-840), through which 'Asketel the cook' and 'Wulfgeat the butler' both receive a similar gift of two virgatae, when 'Wulfnoth the dish-bearer' receives a much higher gift of two hides, a fishery and a church. ${ }^{68}$ But this charter, known from fifteenth- to seventeenthcentury copies, is a post-Conquest forgery, even a 'palpable forgery' according to one of the commentators quoted in the Sawyer catalogue: ${ }^{69}$ we cannot use it as proof. The second document is a post-Conquest charter mentioning individuals whose career had begun before 1066. In 1072 at Wilton nunnery, a small group of clerics and laymen gathered around the dowager queen Edith, Edward the Confessor's widow, in order to witness the sale of land at Combe St Nicholas, Somerset, by Atzor son of Thored, a former dish-bearer of Edward, to Giso, bishop of Wells. ${ }^{70}$ The witness-list includes two officers of the mouth, who bear no title here but who are known from other documents: Hearding 'the queen's butler', known form the (re-)foundation charter of Waltham abbey in 1062, and Godwine hos, probably 'the queen's dish-bearer' in the same Waltham charter. ${ }^{71}$ The two cooks, Ægelric and Rabel, come

65 See among others the case of Peter 'chief of bakers' (pistorum princeps) mentioned by Ermoldus Nigellus in his Poem for Louis the Pious: Depreux, Prosopographie, 349.

66 Bournazel, Louis VI, 224: at Montfort-sur-Risle and Pont-Audemer in 1123, a troop of the French Vexin, commanded by Louis pincerna and Harcher cocus, defeated the knights of Henry I, duke of Normandy and king of England.

${ }^{67}$ Guillot and Sassier, Pouvoirs et institutions, 251.

68 S 189: Asketelli coqui mei; Wulgeti pincernce mei; Wulnoti dapiferi mei.

${ }^{69} \mathrm{http}$ ://www.esawyer.org.uk/charter/189.html [accessed 12 Jun 2015], quoting R. Kay, 'Wulfsige and ninth-century Northumbrian chronology', Northern History, xix (1983), 8-14.

70 I take the text from F. H. Dickinson, 'The sale of Combe', Somersetshire Archaeological and Natural History Society's Proceedings, xxii (1876), 106-13. See the commentary in S. Keynes, 'Giso, Bishop of Wells (1061-88)', Anglo-Norman Studies, xix (1997), 203-71.

${ }^{71}$ S 1036: regine pincerna, regine dapifer. See below for a discussion of this charter. 
at the bottom of the list: 72 probably they were not among the most dignified members of the little company gathered around Edith at Wilton, at least not of the same class as Hearding, Godwine hos and other witnesses who attested at the top of the list, just after the clerics. The sale of Combe was not a royal diploma but a private document, drawn in presence of a dowager queen whom William I had relegated to her estates and who did not personally attest the document. The social level of the witnesses may be considerably lower in that kind of transactions than in the major occasions which make the great majority of other occurrences of officers of the mouth. We may then safely remove cooks and bakers from our officers of the mouth and concentrate on dish-bearers and butlers.

The word discpegn, the main Old English term for a seneschal, may be compared to its cognates burpegn ('chamber-servant') and hroeglpegn ('clothes-servant'), both equivalents of Latin camerarius (chamberlain), sometimes uestiarius ('in charge of the wardrobe'), ${ }^{73}$ and probably also custos (guardian) if we understand this way the mention of three custodes in a charter of Eadred issued in 959. ${ }^{74}$ Both words suggest that court officials were counted among the pegnas or ministri, words which originally meant 'servants'. But thegns, as we know, were in fact noblemen, aristocrats, generally warriors. ${ }^{75}$ Court offices such as those we are reviewing brought much prestige, and service close to the king, the queen, or a powerful person, was noble service. Serving the king or any other grandee in their hall was an 'honour', with all the implications of that term in the early Middle Ages: it was an occupation, a revenue, a source of prestige. Still, the question remains: if they were important, how important were they?

At least since the publication of Simon Keynes's seminal work on The Diplomas of Athelred 'the Unready', ${ }^{76}$ historians of Anglo-Saxon England have used charters subscriptions to assess the rank and relative importance of members of a given court: roughly speaking-and considering all limitations due to the nature of the source and to the shortcomings of transmission - the rank of a individual or a category of officials is deemed to

72 Dickinson, 'Sale of Combe', 107: Agelric coc, Rabel coc.

73 DOE, 'burpegn', has 11 entries from genres as varied as glossaries, poetry, chronicles, homilies and charters. Bosworth and Toller, Anglo-Saxon Dictionary, 'hrægelpegn', provides references from monastic rules, chronicles and charters.

${ }^{74}$ S 658 (Abing 83).

75 S. Keynes, 'Thegn', in The Blackwell Encyclopaedia of Anglo-Saxon England, ed. M. Lapidge et al. (Oxford, 1999), 443-4.

${ }^{76}$ S. Keynes, The Diplomas of Athelred 'the Unready', 978-1016. A Study in Their Use as Historical Evidence (Cambridge, 1980). 
be reflected in the frequency of their appearance and their rank within a witness-list. ${ }^{77}$ As our appendix shows, officers of the mouth in late Anglo-Saxon courts generally attested charters in the middle of the lists, after the royal family, bishops and ealdormen, but at the head of thegns, that is before the indiscriminate number of ministri without any special employment: their position was exactly the same as that of bur-and hroeglpegnas, which means that they were probably thought of as a unified group of 'household officials'. Still, in many charters they were not given any specific title, and only prosopographical study shows that one Eanulf minister or one Ælfheah minister are probably the same ones who attest another charter as disciferi. On the other hand, the counterparts of continental constables ('counts of the stable') and marshals ('horse-servants') were rarely mentioned in English witness-lists: it means they would have attested among ordinary ministri. That confirms Loyn's idea that 'household officers' ranked higher than 'military officers' in Anglo-Saxon courts. ${ }^{78}$ The less visible, and surely less important, role of officials in charge of the royal stables may seen as validating the classic idea of the lesser prominence of cavalry among the Anglo-Saxons. ${ }^{79}$

King Eadred's will, drawn before his death in 955, is particularly interesting for us because household officials are mentioned not in a witness-list but in the main body of the charter, which provides for gifts in cash to the highest members of the body politic: just as witness-lists, this vernacular document may be used to gauge their relative positions. ${ }^{80}$ The archbishop of Canterbury was to receive two hundred mancus; the other bishops and the ealdormen one hundred and twenty mancus; the discpegn, hroeglpegn and birele eighty mancus; the moessepreostan (chaplains) fifty mancus and five pounds in silver pennies; the other priests five pounds in pennies; and the stigweard (stewards) thirty mancus. ${ }^{81}$ Here the

77 Ibid., 155.

78 Loyn, Governance, 99.

${ }^{79}$ It is an old idea, which is still under scrutiny. H. M. Chadwick, The Origin of the English Nation (Cambridge, 1907), 159, showed that the fyrd was a mounted force and that Anglo-Saxon armies used horses for travel and transport, but he did not suggest that they fought from their horses; G. Halsall, Warfare and Society in the Barbarian West, 450-900 (London, 2003), 180-8, challenged this view, and has been supported by R. Lavelle, Alfred's Wars. Sources and Interpretations of Anglo-Saxon Warfare in the Viking Age (Woodbridge, 2010), 134-5.

${ }^{80}$ S 1515 (WinchNM 17). See F. E. Harmer, Select English Historical Documents of the Ninth and Tenth Centuries (Cambridge, 1914), 34-5 and 64-5. Old English was the ordinary language of wills, which explains for the vernacular vocabulary of this charter: L. Tollerton, Wills and Will-Making in Anglo-Saxon England (York, 2011), 22-4.

81 The mancus, whose name was probably derived from an Arabic golden coin some eighth-century Anglo-Saxon kings (including Offa of Mercia) tried to imitate, became in ninth- and tenth-century England a unit of accountancy equivalent to 30 silver pennies (or $£ 1 / 8$ ): P. Grierson, 'Carolingian Europe and the Arabs: the myth of the mancus' (1954), reprinted in Dark Age Numismatics (London, 1979), n. III. Equivalences in pounds would be: archbishop, $£ 25$; bishops and ealdormen, $£ 15$; household officials, $£ 10$; head chaplains, $£ 101 \frac{1}{4}$; other priests, $£ 5$; stewards, $£ 3$ 3/4. 
household officials, including the two officers of the mouth, can be considered as lay equivalents of the main royal chaplains: they receive a bit less, but were mentioned first. It means they were above ordinary thegns just like moessepreostan were above ordinary priests. More exactly, if we are to take the Old English words seriously, they were thegns, but with something more.

It is true that this elevated position is not always apparent. Two examples from the reign of Æthelstan (924-939) mention disciferi after the other ministri. But the first case is in fact an abbreviated list in a cartulary that only mentions the existence of ceteri duces, ministri et disciferi, without giving their names; ${ }^{82}$ as for the second one, it is a subscription list copied into the Durham Liber vitae, identified by Eric Barker: ${ }^{3}$ in both case, there is no sure guarantee that the original order was kept. So this 'standard' hierarchy-first bishops and ealdormen, then household officials, then other thegns - seems quite secure for the period in which our charters are more numerous, between 925 and 1015, that is during the reigns of Edward the Elder's children, grandchildren and great-grandchildren. Conversely, it would be wrong to assume that officials titles referred to similar offices and positions within the court in periods before and after that one: just as their precise functions and hierarchy differed from one country to another, it would have been the same from one period to another. It is then very important to assess and understand the position of our household officials within the particular setting of their times and places: the situation as observed in the time of Eadred or Æthelred II cannot be used as a clue for understanding eighth-century Mercia or Edward the Confessor's court.

The situation in early Anglo-Saxon courts is and will remain obscure. We can only observe it from the middle of the eighth century, with one example from Kent and three from Mercia. ${ }^{84}$ There are no examples from the seventh century: Margaret Deanesly tried to prove that both offices and titles existed at the court of Kent in the early seventh century, but Wilhelm Levison convincingly demonstrated that her case relied on interpolated documents and cacographies from later cartularies, which could not be used as proof for the early existence of household offices in the reign of Æthelberht. The birelas who serve eorlas and ceorlas in the laws of Æthelberht were women and not court officials: it was considered an

${ }^{82}$ S 397 (Burt 3).

${ }^{83}$ The list is at fol. 12v of the Durham Liber vitae (British Library, Cotton Domitian, ms. vii); it is published in E. E. Barker, 'Two lost documents of King Athelstan', Anglo-Saxon England, vi (1977), 137-43, at 138-9.

${ }^{84}$ M. Deanesly, 'The court of King Æthelberht of Kent', Cambridge Historical Journal, vi/2 (1942), 101-14; W. Levison, 'The charters of King Ethelbert I of Kent and the descent of the Anglo-Saxon charters', in England and the Continent in the Eighth Century (Oxford, 1946), 174-233. 
offense to sleep with one of them. ${ }^{85}$ Early officers of the mouth were probably imitations of their Frankish counterparts, where they are first mentioned in mid-seventh-century Merovingian diplomas. ${ }^{86}$ The fact that our earliest example is from Kent ${ }^{87}$ rather strengthens the idea of an imitation of Frankish usage, but the very small number of attested eighth- and early ninth-century English officials - three pincernae and only one discifer - means that any conclusion about them is bound to be shaky. Moreover, Mercian usage appears to have been rather fluctuating, though it seems that, contrary to later usage, offices of the mouth could be combined with the highest military and civil commands $(d u x)$. The only discifer, Eata, is called dux et discifer: we know him from other charters as an official who had a long carrier at Offa's court before attesting in 785 the charter which gave him those titles. ${ }^{88}$ Even if the word $d u x$, in the ninth century, was not used in Mercian charters as consistently as in the tenth century (when it always meant an ealdorman), it was always used for the highest officers of the kingdom. ${ }^{89}$ A charter of Uhtred, sub-king of the Hwicce, has one Dudda pincerna at the very the end of the witness-list, ${ }^{90}$ but the characters before are called princeps-probably members of former royal dynasties (and, as such, maybe kinsmen of Uhtred) - and praefectus - an officer at the head the royal household, the equivalent of a Frankish maior domus, 'mayor of the palace'. ${ }^{91}$ Dudda was probably an important member of the Hwiccian sub-king's entourage, maybe the same one who, some years later, was mentioned a charter of another Hwiccian sub-king, Aldred: being the beneficiary of that charter, he unfortunately did not witness it, and in the body of the text he is only called a fidelis minister. ${ }^{92}$

Wigheard, pincerna in 809 of Coenwulf, king of the Mercians, ${ }^{93}$ is a more difficult case. One Wigheard is almost systematically found in that king's retinue, where he is most frequently titled $d u x$. He once appears as $p^{\prime}$ in the middle of a list where a lot of principes attest: ${ }^{94}$ probably $p$ ' does not stand here for pincerna. Wigheard's case is a difficult one. Simon Keynes's Annotated List identifies two Wigheards, a pincerna and a dux: indeed, both

${ }^{85}$ Laws of Æthelberht, $§ 14$ and 16, in Die Gesetze der Angelsachsen, vol. 1: Text und Übersetzung (Halle, 1903), 4.

${ }^{86}$ Schubert, 'Reichshofämter', 434.

${ }^{87} \mathrm{~S} 24$ (CantCC 11): we know nothing else about this pincerna, who is 'Dunwalh 1' in PASE.

${ }^{88} \mathrm{~S}$ 124: he is 'Eata 5' in PASE.

${ }^{89}$ A. Thacker, 'Some terms for noblemen in Anglo-Saxon England, c. 650-900', Anglo-Saxon Studies in Archaeology and History, ii (1981), 201-36, at 206-7.

$90 \mathrm{~S} 57$.

91 Thacker, 'Some terms for noblemen', 205 and 212.

92 S 114: he is 'Dudda 4' in PASE.

${ }^{93} \mathrm{~S} 164$ (CantCC 41).

${ }^{94} \mathrm{~S} 1260$. 
attest the same charter in $809 .{ }^{95}$ But only two other charters (from 814 and 816) show two Wigheards attesting together, and this time they are a $d u x$ and a simple minister: ${ }^{96}$ it means that there is no proof either that Wigheard pincerna and Wigheard $d u x$ were different people, or that they were one and the same person. PASE actually offers another suggestion: it also finds two Wigheards, 'Wigheard 6' being a simple minister, and 'Wigheard 7' being both pincerna and dux. But that proposition is not valid, since PASE identifies as one and the same person ('Wigheard 7') the two Wigheards who attest S 164, one Wisheard (sic) dux and one Wigheard pincerna. It means that two, three or even four Wigheards may have been known at the Mercian court in the early ninth century: a $d u x$, often at the bottom of lists, in $802-9 ;{ }^{97}$ a pincerna in $809 ; 98$ a $d u x$ in 814-6 (the same $d u x$ ? another one? the same as the pincerna?); ${ }^{99}$ a modest minister in 814-6 (the same as the pincerna?). ${ }^{100}$ Any hypothesis on the identifications of those four possible Wigheards is doomed to be speculative, and we are left with more questions than answers about the place of butlers in early ninth-century Mercia.

The same kind of difficulty awaits us in the exploration of court officials in the reign of Edward the Confessor (1042-1066). There is a gap in our documents for the period of Danish dominance: no charter of Cnut and his sons mention a dapifer or a pincerna, and the wars of 1013-7 seem to have disorganized the order of the court ${ }^{101}$ Even in Edward's reign useful charters are few, and they seldom place officers of the mouth in parallel with other categories such as stallers. In that respect, the (re-)foundation charter of Waltham Abbey, dated from 1060, is a remarkable exception, as it ends with an impressive list of court officials. ${ }^{102}$ It is only known by late copies (from the thirteenth to the seventeenth century), and one needs to be careful when handling it: it is probably a post-Conquest forgery, and its attestations are not always coherent. However, its usefulness has been recognized as it probably incorporates earlier elements, including (crucially) in the witness-list. ${ }^{103}$

\footnotetext{
${ }^{95}$ Keynes, Annotated Atlas, table xvii.

$96 \mathrm{~S} 173$.

97 S 154, S 1260, S 1187, S 40 (CantCC 38), S 161 (CantCC 37), S 164, S 173.

98 S 164.

${ }^{99} \mathrm{~S} 173, \mathrm{~S} 180, \mathrm{~S} 179$.

100 S 173, S 177 (CantCC 48), S 179.

101 T. Bolton, The Empire of Cnut the Great. Conquest and the Consolidation of Power in Northern Europe in the Early Eleventh Century (Leiden-Boston, 2009), 14-5.

102 S 1036.

103 The latest edition is in J. Conway Davies, The Cartee Antiquce. Rolls 11-20 (1960), 34-8. See also the discussion in W. Winters, 'Historical notes on some of the ancient manuscripts formerly belonging to the monastic library of Waltham Holy Cross', Transactions of the Royal Historical Society, vi (1877), 203-66. The reliability of the witness-list and of its rather pompous titles is vindicated by S. Keynes, 'Regenbald the Chancellor (sic)', Anglo-Norman Studies, x (1988), 185-222, at 200-8.
} 
The first person to attest the Waltham charter after the higher clergy and earls was one 'Esgarus', regie procurator aule: he is better known to us as Asgar, ${ }^{104}$ a well-known 'staller'. This title was adapted from Latin (con-)stabulator (in other words, constable) which, in the $1060 \mathrm{~s}$, and was given to prominent courtiers, below the rank of earls but above simple thegns: ${ }^{105}$ this is how the word stabulator should be translated, and not 'constable' following the etymology, since we have no other proof of the existence of that office in England. Asgar witnessed several charters of Edward. One for Peterborough has the 'signum Asgari regis dapiferi':106 his position here, along with that of another dapifer regis called 'Raulfus' (to whom I will come back later), is congruent with tenth-century usage, between the earls and mere ministri. Conversely, Asgar attested the Waltham charter as regie procurator aule in a very prominent position, far above two pincernae and three dapiferi. Between them are nine characters: the first three (Robert fitz Wimarch, Ralph 'the Staller' and Bondig) are known to have been stallers; then there is a kinsman of the king (Osbern); the chancellor (Regenbald) and two chaplains; and two principes (Brihtric and Ælfstan) who go with a long list of other principes (here, a synonym of ministri) below. The Waltham charter has rather grandsounding titles instead or the ordinary ones: aulicus (for Ralph) and palatinus (for Bondig) seem to be smart translations of 'staller', and princeps replaces minister: regie procurator aule, meaning 'in charge of the king's hall', sounds a good translation for dish-bearer. There are two possible explanations (not mutually exclusive) for Asgar's elevated position in the Waltham charter. First, being both a staller and a dish-bearer, Asgar could have attested the charter as a staller: it confirms that, during the Danish domination of the early eleventh century, stallers had been inserted in the court hierarchy in a slot between earls (earlier ealdormen) and thegns (and household officers among them). ${ }^{107}$ The second explanation is that Asgar was a grandson of Tovi the Proud, a Danish-born housecarl who had first founded Waltham Abbey under the reign of Cnut. ${ }^{108}$ Asgar's position in the charter could then be the result of his own connection with Waltham, which through this charter was re-founded and newly endowed by Harold Godwineson, with King Edward's consent.

$104 \mathrm{He}$ is 'Asgar 1' in PASE.

$105 \mathrm{~K}$. Mack, 'The stallers: administrative innovations in the reign of Edward the Confessor', Journal of Medieval History, xii (1986), 123-34.

${ }^{106}$ S 1029 (Pet 23).

107 Mack, 'Stallers'.

108 The story is told in the twelfth-century Waltham Chronicle: The Waltham Chronicle. An Account of the Discovery of Our Holy Cross at Montacute and its Conveyance to Waltham, ed. L. Watkiss and M. Chibnall (Oxford, 1994). 
Another officer at the time of Edward is Atzor, a thegn who attested charters from 1019 to 1062 under four successive kings: only in the Waltham charter does he appears as a dapifer. ${ }^{109}$ Ralph 'the Staller' is even more interesting: ${ }^{110}$ maybe of continental origin, he had married into a Breton family and regularly appeared at court in the 1040s and 1050s. In Edward's charters he is once aulicus, ${ }^{111}$ once regis dapifer, ${ }^{112}$ once procurator, ${ }^{113}$ twice $d u x$ (with no convincing reason: he is not known to have ever been an earl before William the Conqueror's accession), sometimes minister, and most of the time staller, both before and after appearing as dapifer. It means that at Edward's court one could be simultaneously staller and dish-bearer, the first title expressing rank, and the second expressing office-a system of parallel hierarchies well-known in other contexts like the Byzantine court, where it was more systematically organized. The word procurator is not frequent in the sources, and in the tenth and eleventh centuries it seems to have been used for contemporary characters only in two sources, the Liber Vitae of Winchester (from 1031) and a 1065 charter in favour of Giso, bishop of Wells, where five procuratores are named. ${ }^{114}$ Several of them are already known to us: Ralph the Staller, Robert fitz Wimarch, ${ }^{115}$ Asgar, Bondig ${ }^{116}$ and Wigod, who in the Waltham charter was called regis pincerna, the king's butler. We have seen that aulicus and palatinus could be smart translations of 'staller': could it be the case for procurator? The problem is that we have no other indication that Wigod could have been a staller, ${ }^{117}$ and his position in the Waltham charter actually excludes him from such a position. Was procurator a term covering all household officers at the royal court? Asgar and Ralph are known as regis dapiferi, ${ }^{118}$ Wigod as regis pincerna, ${ }^{119}$ and Robert and Bondig as stabulatores, ${ }^{120}$ that is stallers; also it is strange that no chamberlain, in the reign of Edward, appears in this little

\footnotetext{
${ }^{109} \mathrm{He}$ is 'Atsere 1 ' in PASE.

$110 \mathrm{He}$ is 'Ralph 2' in PASE.

$111 \mathrm{~S} 1036$.

112 S 1029 (Pet 23).

113 S 1042 (Wells 40): I take the text of the charter from S. Keynes, 'Giso', 260-2. Keynes writes that 'though irregular in form, there is nothing in the formulation of the charter which is incompatible with the supposition that it was drawn up in $1065^{\prime}$ ' (p. 234).

114 S 1042 (Wells 40).

${ }^{115} \mathrm{He}$ is 'Robert 14' and 'Rodbert 2' in PASE, which curiously does not link them.

$116 \mathrm{He}$ is 'Bondig 1' in PASE.

${ }^{117} \mathrm{He}$ is 'Wigod 2' in PASE, and probably also 'Wigod 4'.

118 S 1029 (Pet 23).

119 S 1036.

${ }^{120}$ Vita Adwardi regis, ii.11, calls Ralph regalis palatii stabilator: The Life of King Edward who rests at Westminster, attributed to a monk of St Bertin, ed. F. Barlow (2nd ed., Oxford, 1992), 118. Domesday Book, Bucks., fol. 151r, also calls Bondig stabulator. I would not translate the word by 'steward', as Barlow does: etymologically, a stabulator was in charge of the stables, not the larder.
} 
group of higher officers: no camerarius, cubicularius, hroeglpegn or burpegn is known to have been a staller, they attest a far more reduced number of charters, and they always attest them after the stallers and after officers of the mouth. The best solution is that procurator was a word for 'staller' in the Giso charter, and that Wigod had become staller between the Waltham charter (in 1062) and the charter for Giso of Wells (in 1065). Then our conclusion must be that some dish-bearers and butlers at Edward's court were chosen among stallers (as were Ralph and Asgar), that some reached that rank (as probably did Wigod), and that others remained king's thegns (an enviable rank in itself). ${ }^{121}$ The introduction of the rank of staller had reshuffled the tidy hierarchy which had been quite stable in the long tenth century.

\section{Social rank and career}

We now know where our officers of the mouth stood within court hierarchy. But was their elevated position at court a result of their office, or were they already major aristocrats before entering the service of the king? German-speaking historians have disagreed about the question whether household officers were aristocrats in their own right who happened to make a career at court, ${ }^{122}$ or servants of servile status who ascended the social ladder thanks to their Königsnähe: indeed, household officials of servile origin seem to have existed at least at the Merovingian and Ottonian courts. ${ }^{123}$ On the contrary, it seems that Anglo-Saxon officers of the mouth were all members of the aristocracy. Of course, it is important to note that we cannot trace the origin of most officers: the ones whose family connections and social rank we can unravel are bound to be of high birth. But there is not any indication of servile dish-bearers and butlers in England, and neither is there in Carolingian Frankia or Capetian France. We have no English equivalent of that Esciko, whom a diploma of Otto III describes as 'our dish-bearer who has been serving us for a long time', a clear formula of servile origin. ${ }^{124}$

As in the case of rank at court, social origin is most difficult to ascertain in early Anglo-Saxon kingdoms; still, it seems more probable that they were of high birth. The early Kentish and Mercian lists do not give us any clue, but in pre-Alfredian Wessex, the title of pincerna appears not to have been bestowed on people of no descent: Asser's Life of King Alfred tells that Æthelwulf's consort and Alfred's mother was Osburh, the daughter of his

${ }^{121}$ A. Williams, The English and the Norman Conquest (Woodbridge, 1995), 72-3.

122 A. Dopsch, The Economic and Social Foundations of European Civilization (1937), 206.

123 Bosl, 'Vorstufen', 246 and 269:

124 Schubert, 'Reichshofämter', 451: Escikoni dapifero nostro nobis diutius serventi. 
'famosus pincerna' Oslac. ${ }^{125}$ Æthelwulf's butler has been linked to an important family who claimed Jutish (for Asser, Gothic) origins, the 'Os- of Hamphsire', which means that, in the early ninth century, the offices of butler and dish-bearer were coveted by members of great families, descendants of former royal dynasties and/or marrying their daughters to royal children. ${ }^{126}$ Similarly, Æthelmod, Æthelwulf’s cellerarius according to one charter, ${ }^{127}$ was from a prominent Kentish family and later became ealdorman of Kent. ${ }^{128}$ In the reign of Alfred, the office of royal dish-bearer could be a step in a brilliant career for members of great families, and several officers are known to have had powerful relations. Sigewulf, Alfred's pincerna in a charter of $892,{ }^{129}$ was a kinsman of Alfred, ealdorman of Kent, who mentioned him in his will: he became ealdorman later in Alfred's reign and died in battle against vikings in $902 .{ }^{130}$ This is consonant with the idea of the ninth-century Wessex court as 'the hub of the West Saxon political order', where aristocrats could make a career only through service of the king. 131

This situation seems to have continued in the tenth century kingdom of the English. Ælfheah, cyninges discðen in a short vernacular charter dated from the year 956-7,132 and discifer in another diploma of the same year, ${ }^{133}$ was also of very high birth. He was the son of Ealhhelm, ealdorman of Mercia in the 940s, and an older brother of Ælfhere, one of the most powerful figures from the mid-950s to his death in $983 .{ }^{134}$ Having started a career in the reign of Eadred, Ælfheah was an important minister at the court of Eadwig in the years 955 and 956, attesting many charters; as we have seen, he was mentioned twice as dish-bearer at the end of that period; and he finally became ealdorman in 959. It is impossible to say if being a dish-bearer was only a short stage in his ascension towards an ealdordom, or if he was already a dish-bearer when he was attesting as a minister (a 'dish-thegn' is after all a thegn). Ann

125 Asser, Life of King Alfred, ch. 2, ed. W. H. Stevenson (2nd ed., Oxford, 1959), 4.

126 J. L. Nelson, 'Reconstructing a royal family. Reflections on Alfred, from Asser, chapter 2', in People and Place in Northern Europe, 500-1600. Essays in honour of Peter Hayes Sawyer, ed. I. N. Wood and N. Lund (Woodbridge, 1991), 47-66.

127 S 293 (CantCC 73): abbreviated as cel' in the charter.

${ }^{128} \mathrm{He}$ is 'Æthelmod 5' and 'Æthelmod 7'; on his family and career, see N. J. Higham and M. J. Ryan, The Anglo-Saxon World (New Haven, 2013), 232-3 and 244.

129 S 348.

${ }^{130} \mathrm{He}$ is 'Sigewulf 6', '7' and ' 8 ' in PASE. The will of ealdorman Alfred is S 1508 (CantCC 96). Sigewulf's death is known from the Anglo-Saxon Chronicle, ms. A, s. a. 903, ed. J. Bately (Cambridge, 1986).

${ }^{131}$ Higham and Ryan, Anglo-Saxon World, 244.

132 S 1292 (Abing 76).

133 S 597 (Abing 55).

134 See how their careers are reconstructed by A. Williams, 'Princeps Merciorum gentis: the family, career and connections of Ælfhere, ealdorman of Mercia, 956-83', Anglo-Saxon England, x (1982), 143-72, and in Keynes, Atlas of Attestations, particularly tables li and lvi. 
Williams, noting that his brother Ælfhere became ealdorman before him in 956, probably has the right answer: '[Ælfheah's] tenure of this office [of dish-bearer] might explain why it was his younger brother who received their father's earldom; the position of seneschal would enable him to exercise patronage on behalf of his kinsmen and was presumably valuable in its own right'. ${ }^{135}$ When the kingdom was divided in 957, the family split its allegiances: Ælfhere joined the court of Edgar and Ælfheah went on serving Eadwig. This was not a mistake but a strategy, and it seems to have worked: after Eadwig's death in 959, Edgar did not dismiss Ælfheah, he made him ealdorman of central Wessex. ${ }^{136}$

Æthelmær 'the Fat' was as powerful as Ælfheah, and of even higher birth. He was the son of Æthelweard (the chronicler, ealdorman of the western shires of Wessex), a patron of Ælfric of Eynsham, and a member of a collateral branch of the royal family descended from Æthelred I. ${ }^{137}$ He began witnessing Æthelred II's charters as minister in the 980s, and we know from a vernacular charter of 1002 that he was then the king's discpen. ${ }^{138}$ Surprisingly, he did not become ealdorman at his father's death in 998. Did Æthelred prefer to keep this important and well-connected servant at his side, did Æthelmær choose to remain at court, or was the king wary not to give him to much power? When Æthelred II made important changes in his government in the middle of the first decade of the eleventh century, Æthelmær retired to the monastery he had recently founded at Eynsham: Barbara Yorke thinks he did it on the order of the king, who did not allow him to retire at Cerne, a house he had founded earlier, ${ }^{139}$ whereas Catherine Cubitt sees it as a natural move at the end of a long career, made in accordance with his wishes and in a monastery into which he had put considerable personal and financial investment. ${ }^{140}$ Whatever the reasons for his retirement, it remains that he retired from political life without having become an ealdorman. He briefly left Eynsham in 1013 and was indeed ealdorman of western Wessex during the crisis at the end of Æthelred's reign: his last known act was to submit to Swein Forkbeard. ${ }^{141}$ As in the case of Ælfheah, Æthelmær's career shows how a member of one of the main aristocratic families of the realm became dish-

135 Williams, 'Princeps Merciorum', 149.

136 Williams, 'Princeps Merciorum', 150.

${ }^{137} \mathrm{He}$ is ' Ethelmær 22' in PASE. On him see: Keynes, Diplomas, 188-192 and 209-13; B. Yorke, 'Aethelmaer: the foundation of the abbey at Cerne and the politics of the tenth century', in The Cerne Abbey Millennium Lectures, ed. K. Barker (Cerne Abbas, 1988), 15-26; C. Cubitt, 'Ællfric's lay patrons', in A Companion to AElfric, ed. H. Magennis and M. Swan (Leiden, 2009), 165-92.

138 S 914 (CantCC 140, OE version).

139 Yorke, 'Aethelmaer', 19-20.

140 Cubitt, 'Ælfric's lay patrons', 191. See also L. Roach, Kingship and Consent in Anglo-Saxon England, 871-978. Assemblies and the State in the Early Middle Ages (Cambridge, 2013), 134-5.

141 Yorke, 'Aethelmaer', 20. 
bearer, and remained so for many years, even when the possibility of an ealdordom opened to him. It confirms that the position was coveted and provided its bearer with a privileged access to the king.

Things were different half a century later, under the reign of Edward the Confessor. Of course, officers of the mouth were still recruited in aristocratic families of the best pedigree. Wigod is called 'the king's kinsman' in a writ of Edward. ${ }^{142}$ Hearding, the queen's butler, was probably the son of Eadnoth the Staller, a member of a wealthy West Country family, well established at the heart of the patrimonial lands of the house of Wessex, whose fortune has been estimated the sixteenth in England on the eve of the Norman conquest. ${ }^{143}$ Here is another confirmation that, in Edward's reign, stallers and officers of the mouth played in the same league, both in wealth and in access to the court. Asgar is another interesting case. He was a descendant of Tovi the Proud, and also a nephew of Osgod Clapa: it means he was related to a kindred that had been very influent at the court of the Danish kings. ${ }^{144}$ But Asgar was not of the highest aristocracy: he was not a member of one of the two highest families (those of Godwine and Leofric) among whom most earls were picked. ${ }^{145}$ Stallers like Asgar did not become earls, and symetrically we do not know that any member of a comital family ever became a dish-bearer or a butler. It may be an indication that, under Edward's reign, offices of the mouth had become less attractive than they had been in the tenth century, probably because much power had shifted from the royal court to the great earldoms. At a time when nearly all earldoms had been monopolized by two families, the service of the king's mouth was still available for members of second-rank aristocratic families, those among whom stallers are found. In the 950s and 990s, Ælfheah and Æthelmær had possibly chosen to remain at court rather than get the ealdordom their family connections allowed them to claim; now in the 1050s and 1060s, Asgar, Ralph and Wigod probably had no choice, as offices of the mouth were the highest and most honourable ones within their grasp, and they still gave access to the king. But Königsnähe in 1060 had become less desirable than it had been in 960 .

142 Keynes, 'Regenbald', 207, quoting no. 104 in Anglo-Saxon Writs, ed. F. E. Harmer (Manchester, 1952).

143 P. Clarke, The English Nobility under Edward the Confessor (Oxford, 1994), 32 and 281-3; P. Stafford, Queen Emma and Queen Edith: Queenship and Women's Power in Eleventh-Century England (Oxford, 1997), 306-18.

144 A. Gautier, 'Osgod Clapa († 1054): pirate, corsaire, mercenaire ou rebelle?', in Histoire navale, histoire maritime. Mélanges offerts à Patrick Villiers, ed. C. Borde and C. Pfister (Paris, 2012), 77-83.

145 F. Barlow, The Godwins. The Rise and Fall of a Noble Dynasty (Harlow, 2002); S. Baxter, The Earls of Mercia. Lordship and Power in Late Anglo-Saxon England (Oxford, 2007). 


\section{Butlers, dish-bearers and Königsnähe}

This brings us to another discussion, that of the special bond that linked a king or a queen to their officers of the mouth. The proximity between rulers and their butlers was stressed in narrative sources, as illustrated by two late stories about Anglo-Saxon kings. In the Passion of Edward the Martyr, the young king is poisoned before being stabbed: the poison is offered by the butler of Ælfthryth, the king's stepmother who wants to get rid of him. ${ }^{146}$ In an episode told by William of Malmesbury, Æthelstan's evil butler persuades his master that his half-brother, the ætheling Edwin, is conspiring against him, which leads to the young prince's unjust death. ${ }^{147}$ In both stories, the butler is shown as the enemy of the young prince, bringing about his unjust death. Of course, these are late stories, probably not very reliable as far as facts are concerned, but they suggest how the physical proximity between an ruler and the person who poured him wine could be resented by other members of the court, who went about telling stories about butlers being evil counsellors.

This emotionally significant proximity between a king and his officers of the mouth may explain why there was some turnover in the attribution of those offices: neither kings nor courtiers would permit any person or lineage to establish a monopoly on such important positions. It was not the case in all western kingdoms of the time. In early Capetian France, officials would pass their title to their sons or brothers. From the 1050 s to the 1120 s, the seneschalship remained in the hands of a few noble lineages of the king's domaine, such as the Rocheforts and the Garlandes. ${ }^{148}$ As for the bouteillerie, it was the preserve of the La Tour de Senlis lineage; 149 only once in a century did it escape the hold of the La Tours, when the Garlandes briefly managed to cumulate all major offices at the royal court in the $1120 \mathrm{~s} .150$ The situation was similar in Normandy, where two brothers of the Ivry family, Hugh and Roger, were butlers of William I from before 1066 to after 1089, and where a father and son, Osbern de Crépon and William Fitz Osbern, were seneschals of Robert the Magnificent and William the Bastard. ${ }^{151}$

146 Passio S. Edwardi, in Edward, King and Martyr, ed. C. E. Fell (Leeds, 1971), 4-5.

147 William of Malmesbury, Gesta regum Anglorum, i, 139, ed. R. A. B. Mynors, R. M. Thomson and M. Winterbottom (2 vols., Oxford, 1998), i. 222-3.

${ }^{148}$ Lemarignier, Gouvernement royal, 154.

149 Ibid., 156-7.

150 Bournazel, Gouvernement capétien, 15.

151 P. Bauduin, La première Normandie ( $X^{e}-X I^{e}$ siècle). Sur les frontières de la haute Normandie: identité et construction d'une principauté (Caen, 2004), 212. 
This was not the case in England, where we do not see that rulers inherited dapiferi and pincernae from earlier reigns: each king appointed his own household, and offices of the mouth were attached not to the 'state' but to the person of the king. Ælfheah only attested as dapifer in the short reign of Eadwig, becoming ealdorman in 959 under Edgar; the many dapiferi who simultaneously attested his brother Edgar's charters only appeared as such in 958, once Edgar had been made king north of the Thames, and they did not attest Eadwig's charters, who reigned in the south for another two years; even if they remained at court, none of them appeared as dapifer or discifer in the following reigns. ${ }^{152}$ Edgar's discifer Eanulf is particularly interesting. His name is relatively rare, ${ }^{153}$ and we may confidently identify several attestations as those of one person. This Eanulf was a close and faithful servant of Edgar's from the beginning of his reign, ${ }^{154}$ who began attesting charters (either as dish-bearer or simply as minister) in 958, and probably ceased to attest in 975.155 These are almost exactly the dates of Edgar's reign, and (most importantly) no Eanulf attested charters of Edward the Martyr or Æthelred. ${ }^{156}$ Of course, Eanulf may have died the same year as Edgar, but he is not known outside charters, and we know nothing else about him: the most likely explanation remains that his office and his presence at court ceased with the death of his master. Similarly, Edward the Confessor's butler Wigod remained an agent of the king after Edward's death, but he is not known to have served either of his successors as butler: he may have been castellan of Wallingford under Harold, and under William I he was a rich landlord with no known position at court. 157

Unfortunately, other disciferi cannot be submitted to the same kind of enquiry, either because they appear too seldom, or because their name is too common to allow any workable conclusion. It remains that we have no example of an officer of the mouth witnessing a charter, with mention of his title, under two successive kings. This may be the result of the scarcity of relevant charters, but I think we can risk the conclusion that their office probably ended with their master's death. This is indeed an indication of the high level of control English kings had over their own court and kingdom. Their officials of the mouth may have

\footnotetext{
152 Keynes, Atlas of Attestations, tables li, lvii, lvii-a, lviii and lxiii.

153 Even if there are two Eanulfs in one charter, S 748.

${ }^{154} \mathrm{He}$ is 'Eanwulf 22' in PASE. J. R. Maddicott, The Origins of the English Parliament, 924-1327 (Oxford, 2010), 9, identifies him as the same Eanulf to whom Edgar gave land at Ducklington, Oxfordshire, at the beginning of his reign: see S 678 (Abing 82); having just become king in Mercia, Edgar needed a reliable man on the border of his brother and competitor Eadwig's kingdom.

155 Keynes, Atlas of Attestations, table lvii-a.

${ }^{156}$ Ibid., tables lviii and lxiii.

157 Williams, The English and the Norman Conquest, 100-2.
} 
been great lords, members of major families, they were always strictly officers, and no family ever captured the household offices. England was not France, where the bouteillers de La Tour de Senlis passed on their office to their sons, to the point that 'Bouteiller' became their surname! The case of the queen's officers confirms this. As opposed to the king, a queen could survive her position and remain around as a dowager, keeping some of her household in her service. The already mentioned charter for the sale of Combe suggests that Hearding and Godwine, Edith's butler and dish-bearer, remained close to her after Edward's death, and were not assigned to the household of new queens.

For families of the aristocracy, such a special bond with the reigning monarch remained important in England over the whole period. It was a good position if one wanted to make a career and secure royal patronage, and it could also prove useful in times of crisis. All the men we have mentioned were of high birth: some of them were of the highest aristocracy, others belonged to middling nobility, others may have been from lower ranges of the thegnly classes. But in all cases, their service of the king, even if it was made possible by their rank, could be part of a career. Wulfgar, Æthelstan's discifer mentioned in the list preserved in the Durham Liber vitae, and Odda, his dapifer in another list, were both among Æthelstan's closest thegns, and both were appointed ealdorman in the reign of his successor Edmund. ${ }^{158}$ Sigewulf under Alfred, Ælfheah under Edgar, and Æthelmær (belatedly) under Æthelred II all became ealdormen, and Wigod the butler may have obtained the title of staller in the last years of Edward the Confessor. Did offices of the mouth work as a kind of 'waiting list' before being appointed to an ealdordom ? Thus their fidelity and efficiency could be tested at close range before they could be given more sensitive regional command. Such careers would be of interest for members of the higher families, but also for members of lesser aristocratic kindreds on the move up the social ladder through royal favour and service.

Proximity with a ruler could also be of use in times of crisis. It may of course be a coincidence that the sale of Combe in 1072 brought together, around the dowager queen Edith, three people whom we know to have been officers of the mouth: Atzor son of Thored, Edward the Confessor's dish-bearer, who was selling land to Giso of Wells; Hearding son of Eadnoth, Edith's butler; and Godwine hos, her own dish-bearer. Pauline Stafford speaks of a 'household of survivors', ${ }^{159}$ and Simon Keynes writes that 'it is as if the surviving members of the Edwardian establishment had gathered in the presence of the Lady Edith for their

158 They are 'Wulfgar 7' and 'Wulfgar 10', and 'Odda 4' in PASE. Sources mentioning them as disciferi are Barker, 'Two lost documents' and S 450. See also Foot, Ethelstan, 69-70; Keynes, Atlas of Attestations, tables xxxix and xlii.

${ }^{159}$ Stafford, Queen Emma and Queen Edith, 122. 
annual convention'. 160 To those three we may add Wigod, the Confessor's pincerna, who became a prosperous baron in post-conquest England. The fact that at least four royal officers of the mouth 'survived' the Conquest may be a result of their quick choice of William's side in the early years, when the new king was still trying to lean on faithful English nobles: Wigod probably opened the Norman army the road to London by letting it cross the Thames at Wallingford. ${ }^{161}$ What is more surprising is their survival after 1070, when many English aristocrats were dispossessed and replaced by landlords of continental origin. One explanation could be found in the special Königsnähe we saw household officers enjoyed with their masters: the fact that the Combe charter also mentions a steward and a chamberlain reinforces this idea. ${ }^{162}$ But that proximity probably played differently for Wigod, Atzor and Hearding (we know next to nothing about their colleague Godwine hos). William did try to show the continuity of his reign with that of Edward by employing close advisors of the late king, such as the stallers Ralph and Robert fitz Wimarch, and several clerics of Edward's entourage had their career boosted, as was the case for his chaplain Osbern:163 Wigod survived and thrived, being the ancestor of some of the few English tenants-in-chief in 1086. ${ }^{164}$ As for Hearding and Atzor, their status seems to have been considerably hampered as a consequence of the Norman conquest, ${ }^{165}$ and they did not get any promotion: Hearding probably had to rebuild his family's estate and influence, for his father's land and his appear not to have been the same. ${ }^{166}$ The patronage of Edith, who had retired to Wilton just after Edward's death, would have been crucial in those difficult circumstances. Did they follow her in her retirement? At least they were was still there six years later on the occasion of the sale of Combe.

\section{Service and title: being a minister}

There remains a last question to ask about officers of the mouth: what exactly did they do? As I said, they were not mere 'waiters', but it is difficult to understand what kind of service they actually performed. In the Carolingian empire their roles were not always clearly

160 Keynes, 'Giso', 244.

161 Williams, The English and the Norman Conquest, 101.

162 Dickinson, 'Sale of Combe', 107: 'Ægelsig stiweard' and 'Alfwold burpen'.

163 D. C. Douglas, William the Conqueror. The Norman Impact upon England (Berkeley-Los Angeles, 1964), 290.

164 Williams, The English and the Norman Conquest, 100-1.

165 Keynes, 'Giso', 245.

166 Williams, The English and the Norman Conquest, 120-2. 
defined, ${ }^{167}$ and neither was it in late eleventh-century France. The bouteiller was supposed to oversee the vineyards and the wine provision, and the sénéchal had wide powers over the organization of the court, ranging from the royal table to the smooth operation of the court; but in fact all of them could be entrusted with many errands and missions, such as presiding over judiciary cases not necessarily connected with their perimeter, or even commanding the royal ost. As Éric Bournazel showed, the only things which really counted were their fidelity, their competence, their valour and their personal charisma. ${ }^{168}$ The service of the royal mouth was part of their description, but it was probably not prominent.

It is true that some narrative sources mention pincernae or byrelas pouring drink for a lord's retinue, as is the case in Beowulf, the Vita Dunstani or the Vita Wulfstani. But given the nature of the sources, we cannot decide whether the characters called butlers in narrative sources were titular of a household office, or whether the word was used for people who served just on the occasion of one meal. ${ }^{169}$ It is indeed possible that officers of the mouth only ministered in great occasions such as coronations, crown-bearings, weddings and major feasts of the Christian calendar. We saw how the Ottonian offices of butler and seneschal could be held by officials of servile origin: such much do we learn for documentary sources. But at the same time, when they are invoked in narrative sources, they appear to have been held by the highest lords of the realm, the Stammesherzöge of historiography-men who did not live at court and who were not in a position to accomplish such a service on a daily basis. Widukind of Corvey tells that, on the occasion of Otto I's coronation at Aachen in 936, the service of the table was fulfilled by Eberhard, duke and Franconia, and that of drinks by Herman, duke of Swabia. ${ }^{170}$ Similarly, in 986 at Quedlinburg, Henry the Quarrelsome, duke of Bavaria, served Otto III 'at the table', while Henry, duke of Carinthia, served him 'at the cellar'. ${ }^{171}$

There are no similar cases of higher lords serving at the king's table at major feasts in Anglo-Saxon contexts. Of course, we cannot be sure that ealdormen could not cumulate their office with that of dapifer. In that matter there is no definitive proof because the title of ealdorman, being more prestigious, would have supplanted that of discifer or pincerna in any

167 Halphen, Charlemagne, 157.

168 Bournazel, Gouvernement, 94-102.

169 See 'B.', Vita Dunstani, x, 6, in The Early Lives of St Dunstan, ed. M. Winterbottom and M. Lapidge (Oxford, 2012), 36-7, where Winterbottom and Lapidge (probably rightly) translate pincernis by 'the waiters'.

170 Widunkind of Corvey, Res gestae Saxonicae, ii, 2, in Die Sachsengeschichte des Widunkind von Korvei, ed. H. E. Lohmann and P. Hirsch (5th ed., Hanover: MGH SS rer. Germ. 1x, 1935), 67.

171 Thietmar of Merseburg, Chronicle, iv, 9, in Die Chronik des Bischofs Thietmar von Merseburg und ihre Korveier Überarbeitung, ed. R. Holzmann (Berlin: MGH SS rer. Germ. nova series ix, 1935), 141: 'Henricus ad mensam [...], Hezil ad cellarium'. 
witness-list; but neither is there any proof that a household title could be held alongside with an ealdordom. The eighth-century Mercian Eatta, dux et discifer, ${ }^{172}$ is unfortunately too early to be of any use for understanding the tenth-century English court. The tenth-century cases of Ælfheah and Æthelmær rather suggest that they abandoned their office at court after becoming ealdormen. The only case I could find is late, probably unhistorical and included in a highly literary episode: Henry of Huntingdon writes that Harold, earl of Wessex, served Edward the Confessor at his table. ${ }^{173}$ Conversely, there are examples of ealdormen or earls feasting side by side with the king, particularly in highly festive occasions when their German counterparts would have served their masters: duces, milites and praefecti dined with King Edgar after his coronation at Bath in 973;174 Godwine, earl of Wessex, died while feasting with Edward the Confessor at Easter 1053. ${ }^{175}$ The English court in this respect was apparently different from the German one, which it resembled in so many other aspects. ${ }^{176}$ We have no indication whatsoever that, in late Anglo-Saxon England, the highest lords of the realm served the king in person, even in great occasions: that was probably left to permanent, and not occasional, butlers and dish-bearers - probably those who bear those titles in witness-listswhose honorific role would have been enhanced in such occasions.

Another hint that officers of the mouth did actually serve, at least at major feasts, is that several of them may attest at the same time: it looks as if teams of officers were operating in the entourage of a king. The appendix shows that the earliest charters, before the reign of Æthelstan - and this means essentially the Mercian charters - mention only one discifer and one pincerna at a time. On the other hand, tenth- and eleventh-century charters often have as much as four dapiferi and disciferi, whereas there is generally only one pincerna, or one for the king and one for the queen, as in the Waltham charter. ${ }^{177}$ Was the dapifer's office split among several dish-bearers while the butler remained alone? It was probably not the case. A charter from the reign of Æthelred II does mention four pincernae:178 even if it does not give the names of the witnesses, it is considered reliable by its editor and other commentators, and must be taken seriously. ${ }^{179}$ The answer may lie in a diploma of Eadwig granting two hides of

\footnotetext{
172 S 124.

173 Henry of Huntingdon, Historia Anglorum, vi, 25, ed. D. Greenway (Oxford, 1996), 379.

174 Byrhtferth of Ramsey, Vita Oswaldi archiepiscopi Eboracensis, iv, 7, in Byrhtferth of Ramsey: The Lives of St Oswald and St Ecgwine, ed. M. Lapidge (Oxford, 2009), 110.

175 Anglo-Saxon Chronicle, ms. C, s. a. 1053, ed. K. O’Brien O'Keeffe (Cambridge, 2000).

176 Roach, Kingship and Consent, 203-4.

177 S 1036.

178 S 853 (Burt 24).

179 http://www.esawyer.org.uk/charter/853.html [accessed 17 Jun 2015].
} 
land to Cenric, his 'most faithful propincernarius'. ${ }^{180}$ This title is curious and unique in our corpus, and could mean both 'first butler' and 'deputy butler'; moreover, an Ælfwig pincerna also witnessed the grant. Again we have several butlers in one charter, but this one suggests that one of them could have been at the head of a team, and the other one a member of it.

Such teams probably also existed for dish-bearers. At the Carolingian court, and also at the French court in the late eleventh century, household officers had full control over a number of lesser servants: the chambrier over chambellans, the bouteiller over échansons, the sénechal over many others. ${ }^{181}$ Indeed the control of those teams was what gave them much agency within the government. ${ }^{182}$ Their vocabulary was more specific than in England: a Carolingian butler may be described as magister pincernarum, ${ }^{183}$ and a Capetian buticularius coordinated a team of pincernae. Maybe tenth- and eleventh-century English usage did not routinely distinguish a king's head butler and his deputy butlers, the head dish-bearers and the deputy dish-bearers? As we have seen, up to four disciferi may attest a diploma with no apparent hierarchy. But the will of Eadred provides for only one discpegn and several stigweard, which suggests the existence of a team with different names for the head and the deputies. ${ }^{184}$ Also, the Vita Dunstani by 'B.' mentions 'overseers of the royal household' (ministrationis regiae preuisores) sent ahead of the court to make sure everything was ready to receive the king and his entourage; ${ }^{185}$ these were probably the same as the foestingmen mentioned in several ninth-century charters from Mercia. ${ }^{186}$ Presumably preuisores or foestingmen belonged to a team supervised by a head dish-bearer, or maybe they worked under the joint supervision of both the head dish- and cupbearers?

Nevertheless, the simultaneous presence of several officers of the mouth suggests that, on major occasions such as the assemblies during which royal diplomas were written and witnessed, ${ }^{187}$ a sizeable team of officers of the mouth was gathered to minister for the king and his guests, maybe under the supervision of two of them. Of course, there was always at least one feast during an assembly, ${ }^{188}$ and the officers' service at the table was much needed if the event was to be a success. It does not mean that, at other times and when the court was not

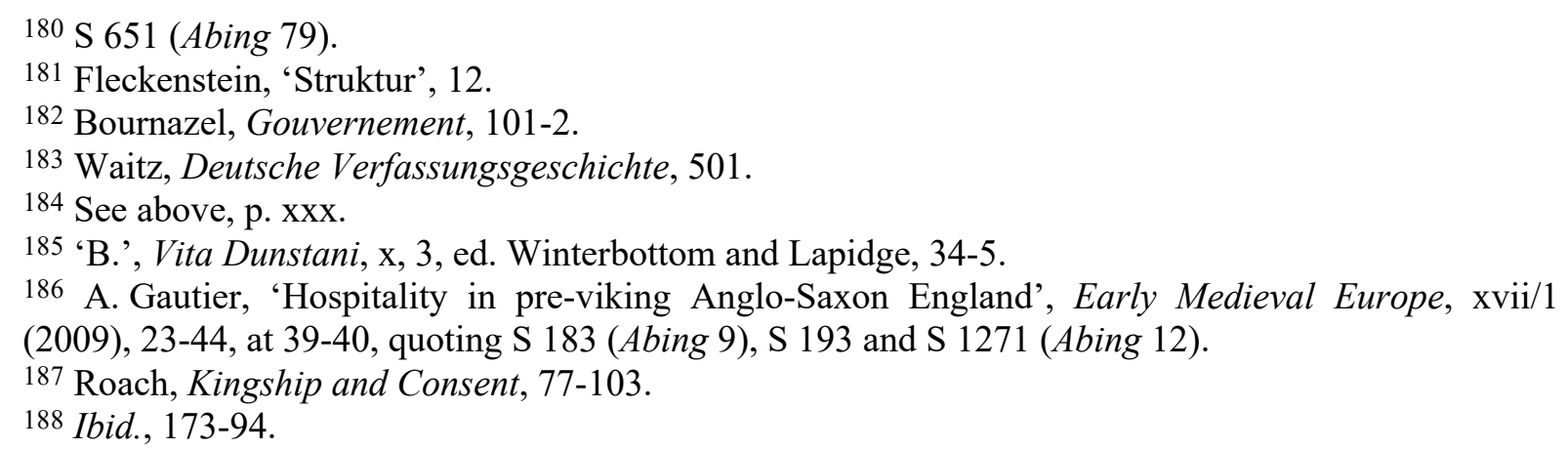


feasting, they did not fulfil many other duties, administrative and military: just as their French counterparts bouteillers and sénéchaux, English byrelas and discpegnas were probably versatile servants of the king.

\section{Conclusion}

Many questions remain, but I think we can nevertheless draw some conclusions. If serving the king at his table could be done by many people-ideally, the queen herself did that, as in Beowulf189 - there were in Anglo-Saxon courts from the eighth century down to the Norman conquest officers who bore household titles, at first probably modelled on their Carolingian counterparts. Those officers, born in families of the elite, were close counsellors of the king; they also had a ceremonial role in special occasions. Our documentation allows us to put (albeit unequally and inadequately) three periods in the spotlight. In eighth- and ninthcentury Mercia and Wessex, offices of the mouth could be held by dukes and ealdormen, that is by the highest military and civil officers, heirs of former royal families and kinsmen of kings. Their status was slightly diminished in the tenth century kingdom of the English, when household offices could be held by members of the principal families prior to obtaining an ealdordom; but with the greater number of officers, those titles were also offered to thegns of lesser influence and origin, who were rewarded by these titles but never went further in their career. Finally, in the mid-eleventh century, officers of the mouth were mainly chosen in the middle ranks of the aristocracy, below the earls but in well-established families whose influence was great at court, but maybe not in the whole kingdom: stallers' families whose sons were now barred from any higher career and who, by personally serving the king or the queen, hoped to maintain their social and political position. This kind of service allowed them some proximity with the king, greater indeed than that enjoyed by the earls, and nearly as useful for making a fortune. And in time of crisis, their Königsnähe proved more resilient than all the earls' fortune and landed power.

189 Beowulf, 1. 1168-9, ed. Fulk, Bjork and Niles, 41. 


\section{Appendix}

'Officers of the mouth' in attestation lists of Anglo-Saxon charters

\begin{tabular}{|c|c|c|c|c|c|}
\hline Sawyer & Date & Issued by & In favour of & $\begin{array}{l}\text { 'Officers of the mouth' } \\
\text { in the attestation list }\end{array}$ & Rank in the list and other observations \\
\hline $\begin{array}{l}\text { S } 24 \\
(\text { CantCC 11) }\end{array}$ & 741 & $\begin{array}{l}\text { Æthelberht II } \\
\text { of Kent }\end{array}$ & $\begin{array}{l}\text { St Mary of Lympne } \\
\text { (Kent) }\end{array}$ & - Dunuualhus pincerna & $\begin{array}{l}\text { - after } 1 \text { archbishop and } 2 \text { untitled people } \\
\text { - before } 3 \text { people including } 1 \text { prefectus }\end{array}$ \\
\hline S 57 & $\begin{array}{l}756 \text { (recte } \\
777 \times 779)\end{array}$ & $\begin{array}{l}\text { Uhtred of the } \\
\text { Hwicce }\end{array}$ & $\begin{array}{l}\text { Ceolmund, his } \\
\text { minister }\end{array}$ & - Dudda pincerna & $\begin{array}{l}\text { - last in the list, after regulus Aldred, bishops and abbots, } 5 \\
\text { principes and } 3 \text { proefecti }\end{array}$ \\
\hline S 124 & 785 & $\begin{array}{l}\text { Offa of } \\
\text { Mercia }\end{array}$ & $\begin{array}{l}\text { St Peter of } \\
\text { Westminster }\end{array}$ & $\begin{array}{l}\text { - Eatta dux et regis } \\
\text { discifer }\end{array}$ & $\begin{array}{l}\text { - after the bishops and } 2 \text { duces } \\
\text { - before } 1 \text { other } d u x \text { and } 2 \text { ministri }\end{array}$ \\
\hline $\begin{array}{l}\text { S } 164 \\
(\text { CantCC 41) }\end{array}$ & 809 & $\begin{array}{l}\text { Coenwulf of } \\
\text { Mercia }\end{array}$ & $\begin{array}{l}\text { Wulfred, archb. of } \\
\text { Cantorbéry }\end{array}$ & - Wigheard pincerna & - last in the list, after 9 duces \\
\hline $\begin{array}{l}\text { S } 293 \\
(\text { CantCC 73) }\end{array}$ & 843 & Æthelwulf & $\begin{array}{l}\text { Ethelmod, his } \\
\text { minister }\end{array}$ & $\begin{array}{l}\text { - Athelmod cel' } \\
\text { - Dera cel' }\end{array}$ & $\begin{array}{l}\text { - cel'probably for cellerarius } \\
\text { - after } 2 \text { duces and } 1 \text { abbot } \\
\text { - before } 5 \text { ministri and several clerics, including } 1 \\
\text { archbishop }\end{array}$ \\
\hline S 348 & 892 & Alfred & Æthelhelm comes & $\begin{array}{l}\text { - Deormod cellerarius } \\
\text { - Sigewulf pincerna }\end{array}$ & $\begin{array}{l}\text { - Deormod appears after } 1 \text { bishop, } 2 \text { duces, Edward the } \\
\text { king's son, } 2 \text { priests } \\
\text { - then comes } 1 \text { treasurer, and Sigewulf } \\
\text { - then } 9 \text { milites }\end{array}$ \\
\hline $\begin{array}{l}\text { S } 396 \\
(\text { Abing 21) }\end{array}$ & 926 & Æthelstan & Ealdred minister & - Wulfhelm discifer regis & $\begin{array}{l}\text { - after the bishops and } 3 \text { duces } \\
\text { - before the ministri }\end{array}$ \\
\hline $\begin{array}{l}\text { S } 397 \\
\text { (Burt 3) }\end{array}$ & 926 & Æthelstan & Uhtred, his fidelis & $\begin{array}{l}\text { - et ceteri duces, ministri } \\
\text { et disciferi } \\
\text { (not named) }\end{array}$ & - after the bishops \\
\hline S 450 & $924 \times 939$ & Æthelstan & St Buryan (Cornwall) & $\begin{array}{l}\text { - Odda discifer } \\
\text { - Helpine discifer }\end{array}$ & $\begin{array}{l}\text { - after the bishops and } 5 \text { duces } \\
\text { - there is one untitled person between Odda and Helpine } \\
\text { - before } 6 \text { ministri and } 1 \text { untitled person }\end{array}$ \\
\hline $\begin{array}{l}\text { S } 597 \\
(\text { Abing 55) }\end{array}$ & 956 & Eadwig & $\begin{array}{l}\text { his adoptiuus parens } \\
\text { Ælfric }\end{array}$ & $\begin{array}{l}\text { - Ælfheah discifer } \\
\text { - Ælfsige discifer }\end{array}$ & $\begin{array}{l}\text { - after the bishops and abbots, } 2 \text { duces, } 1 \text { comes, } 4 \text { duces } \\
\text { - before } 1 \text { untitled person and } 8 \text { ministri }\end{array}$ \\
\hline
\end{tabular}




\begin{tabular}{|c|c|c|c|c|c|}
\hline & & & & - Ælfsige discifer & \\
\hline $\begin{array}{l}\text { S } 1292 \\
(\text { Abing 76) }\end{array}$ & $956 \times 957$ & \multicolumn{2}{|c|}{$\begin{array}{l}\text { Agreement between Brihthelm, } \\
\text { bishop, and Æthelwold, abbot of } \\
\text { Abingdon, sanctioned by King } \\
\text { Eadwig }\end{array}$} & $\begin{array}{l}\text { - \#lfheah cyninges } \\
\text { discðen }\end{array}$ & $\begin{array}{l}\text { - after the queen, the queen’s mother, the bishops and } 1 \\
\text { ealdorman } \\
\text { - before Eadric, Ælfheah brother }\end{array}$ \\
\hline $\begin{array}{l}\text { S } 651 \\
\text { (Abing 79) }\end{array}$ & 958 & Eadwig & $\begin{array}{l}\text { Cenric, } \\
\text { fidelissimus } \\
\text { propincernarius }\end{array}$ & $\begin{array}{l}\text { - Ealdred regis discifer } \\
\text { - Alfuuig regis pincerna }\end{array}$ & $\begin{array}{l}\text { - after the bishops and } 2 \text { propinqui regis } \\
\text { - before } 6 \text { ministri }\end{array}$ \\
\hline $\begin{array}{l}\text { S } 658 \\
(\text { Abing 83) }\end{array}$ & 959 & Eadwig & $\begin{array}{l}\text { Abingdon Abbey } \\
\text { (Berks.) }\end{array}$ & $\begin{array}{l}\text {-Wulfgar discifer } \\
\text { - Æpelsige pincerna }\end{array}$ & $\begin{array}{l}\text { - after the bishops and abbots, } 1 \mathrm{dux}, 3 \text { custodes, } 3 \text { ministri } \\
\text { - before more than } 50 \text { ministri }\end{array}$ \\
\hline $\begin{array}{l}\text { S } 768 \\
(\text { Burt 23) }\end{array}$ & 968 & Edgar & $\begin{array}{l}\text { Wulfric, bishop (of } \\
\text { Dorchester? } \\
\text { of Hereford?) }\end{array}$ & $\begin{array}{l}\text { - Eanulf discifer } \\
\text { - \#lfwine discifer } \\
\text { - Wulfstan discifer }\end{array}$ & $\begin{array}{l}\text { - after the bishops and } 5 \text { duces } \\
\text { - before } 1 \text { pedisecus and } 6 \text { ministri }\end{array}$ \\
\hline $\begin{array}{l}\text { S } 782 \\
(\text { Pet } 15)\end{array}$ & 971 & Edgar & $\begin{array}{l}\text { Æthelwold, bishop } \\
\text { of Winchester }\end{array}$ & $\begin{array}{l}\text { - \#theluuard disc’ } \\
\text { - Enulf disc } \\
\text { - \#lsige disc } \\
\text { - \#Elfuuard disc }\end{array}$ & $\begin{array}{l}\text { - after the bishops, the abbots and } 4 \text { duces } \\
\text { - before } 16 \text { untitled people } \\
\text { - discipulus is surely a mistake for the abbreviation disc' } \\
\text { (discifer) }\end{array}$ \\
\hline S 792 & 974 & Edgar & $\begin{array}{l}\text { Thorney Abbey } \\
\text { (Cambs.) }\end{array}$ & $\begin{array}{l}\text { - Æpelard disc’ } \\
\text { - Eanulf disc’ } \\
\text { - Ælfsige disc’ } \\
\text { - Ælfweard disc’ }\end{array}$ & $\begin{array}{l}\text { - after the bishops, the abbots and } 4 \text { duces } \\
\text { - before } 20 \text { untitled people }\end{array}$ \\
\hline $\begin{array}{l}\text { S } 853 \\
(\text { Burt 24) }\end{array}$ & 984 & Ethelred II & $\begin{array}{l}\text { Elfwine, the } \\
\text { king's scriptor }\end{array}$ & $\begin{array}{l}\text { - ceteri duces sex, } \\
\text { abbates iiij }^{\text {or }} \text {, disciferi } \\
\text { iiijor }^{\text {or }} \text {, pincerne iiij } \\
\text { ministri vndecim } \\
\text { (unnamed) }\end{array}$ & - after the bishops \\
\hline \multirow[t]{2}{*}{$\begin{array}{l}\text { S } 914 \\
(\text { CantCC 140, } \\
\text { OE version) }\end{array}$} & \multirow[t]{2}{*}{$\begin{array}{l}1006 \\
\text { (recte 1002) }\end{array}$} & \multirow[t]{2}{*}{ Ethelred II } & \multirow[t]{2}{*}{$\begin{array}{l}\text { Christ Church, } \\
\text { Canterbury }\end{array}$} & $\begin{array}{l}\text { - \#ðelmær mines } \\
\text { hlafordes discpen }\end{array}$ & $\begin{array}{l}\text { - after the bishops, the abbots and the ealdormen } \\
\text { - before } 11 \text { people, most of them untitled, but with } 2 \text { cinges } \\
\text { Jegnas and } 1 \text { hroegelpen }\end{array}$ \\
\hline & & & & \multicolumn{2}{|c|}{$\begin{array}{l}\text { - there is a Latin version: Æthelmær is in the same position, just after the duces, but } \\
\text { with the title of minister, and all others after are also ministri }\end{array}$} \\
\hline S 1422 & $1007 \times 1014$ & The community & Ætheling Edmund & - Lofwine apelinges & - before the bishops, 2 ealdormen, "the elders of the thegnas \\
\hline
\end{tabular}




\begin{tabular}{|c|c|c|c|c|c|}
\hline (Sherb 14) & & $\begin{array}{l}\text { of Sherborne } \\
\text { (Dorset) }\end{array}$ & $\begin{array}{l}\text { (future king } \\
\text { Edmund Ironside) }\end{array}$ & discpen & $\begin{array}{l}\text { of Dorset", } 2 \text { priests } \\
\text { - before } 2 \text { cnihtas of the cetheling and the men of the hired }\end{array}$ \\
\hline $\begin{array}{l}\text { S } 1531 \\
(\text { ASWills 81) }\end{array}$ & $1043 \times 1045$ & \multicolumn{2}{|c|}{$\begin{array}{l}\text { Will of Thurstan, son of Wine, thegn } \\
\text { from East Anglia }\end{array}$} & - Leuerich discpeng & $\begin{array}{l}\text { - last witness for Essex (the witnesses are arranged by shire): } \\
\text { the five previous witnesses for Essex do not have any title, } \\
\text { but the first is Ælfgar, son of Earl Leofric of the Mercians }\end{array}$ \\
\hline $\begin{array}{l}\text { S } 1029 \\
(\text { Pet } 23)\end{array}$ & 1060 & $\begin{array}{l}\text { Edward the } \\
\text { Confessor }\end{array}$ & $\begin{array}{l}\text { Peterborough Abbey } \\
\text { (Hunts.) }\end{array}$ & $\begin{array}{l}\text { - Raulfus regis dapifer } \\
\text { - Asgærus regis dapifer }\end{array}$ & $\begin{array}{l}\text { - after the bishops and duces (Harold and Tostig) } \\
\text { - before several people }\end{array}$ \\
\hline S 1036 & 1062 & $\begin{array}{l}\text { Edward the } \\
\text { Confessor }\end{array}$ & $\begin{array}{l}\text { Waltham Holy Cross } \\
\text { Abbey (Essex) }\end{array}$ & $\begin{array}{l}\text { - Esgarus regie } \\
\text { procurator aule } \\
\text { - Wigodus regis pincerna } \\
\text { - Herdingus regince } \\
\text { pincerna } \\
\text { - Adzurus regis dapifer } \\
\text { - Yfingus regis dapifer } \\
\text { - Godwinus regince } \\
\text { dapifer }\end{array}$ & $\begin{array}{l}\text { - Esgarus is mentioned just after the bishops, abbots and } \\
\text { comites } \\
\text { - after Esgarus come } 9 \text { people: Rodbertus regis } \\
\text { consanguineus, Radulfus regis aulicus, Bundinus regis } \\
\text { palatinus, Hesbernus regis consanguineus, } 1 \text { regis } \\
\text { cancellarius, } 2 \text { regis capellani, } 2 \text { principes } \\
\text { - the } 2 \text { pincernae and the } 3 \text { dapiferi of the king and queen } \\
\text { are then mentioned } \\
\text { - then come } 11 \text { principes }\end{array}$ \\
\hline $\begin{array}{l}\text { S } 1042 \\
(\text { Wells 40) }\end{array}$ & 1065 & $\begin{array}{l}\text { Edward the } \\
\text { Confessor }\end{array}$ & Giso, bishop of Wells & - Heardyng pincerna & $\begin{array}{l}\text { - after the bishops, abbots, duces, } 5 \text { procuratores } \\
\text { - before } 1 \text { cubicularius, } 3 \text { principes, } 4 \text { untitled people and } 7 \\
\text { ministri }\end{array}$ \\
\hline
\end{tabular}

